\title{
Production of biodiesel from microalgae through biological carbon capture: a review
}

\author{
Madhumanti Mondal $^{1}$ - Shrayanti Goswami ${ }^{1}$ - Ashmita Ghosh ${ }^{2}$ - Gunapati Oinam ${ }^{3}$. \\ O. N. Tiwari ${ }^{4}$ - Papita Das ${ }^{5}$ - K. Gayen ${ }^{2}$ M. K. Mandal ${ }^{1}$ - G. N. Halder ${ }^{1}$
}

Received: 9 November 2016/Accepted: 6 April 2017/Published online: 30 May 2017

(C) Springer-Verlag Berlin Heidelberg 2017

\begin{abstract}
Gradual increase in concentration of carbon dioxide $\left(\mathrm{CO}_{2}\right)$ in the atmosphere due to the various anthropogenic interventions leading to significant alteration in the global carbon cycle has been a subject of worldwide attention and matter of potential research over the last few decades. In these alarming scenario microalgae seems to be an attractive medium for capturing the excess $\mathrm{CO}_{2}$ present in the atmosphere generated from different sources such as power plants, automobiles, volcanic eruption, decomposition of organic matters and forest fires. This captured $\mathrm{CO}_{2}$ through microalgae could be used as potential carbon source to produce lipids for the generation of biofuel for replacing petroleum-derived transport fuel without affecting the supply of food and crops. This comprehensive review strives to provide a systematic account of recent developments in the field of biological carbon capture through microalgae for its utilization towards the generation of biodiesel highlighting the significance of certain key parameters such as selection of efficient strain, microalgal metabolism, cultivation systems (open and closed) and biomass production along with the
\end{abstract}

G. N. Halder

gopinathhaldar@gmail.com

1 Chemical Engineering Department, National Institute of Technology, Durgapur, India

2 Chemical Engineering Department, National Institute of Technology, Agartala, India

3 Institute of Bioresources and Sustainable Development, Imphal, India

4 Division of Microbiology, Indian Agricultural Research Institute, New Delhi, India

5 Chemical Engineering Department, Jadavpur University, Jadavpur, India national and international biodiesel specifications and properties. The potential use of photobioreactors for biodiesel production under the influence of various factors viz., light intensity, $\mathrm{pH}$, time, temperature, $\mathrm{CO}_{2}$ concentration and flow rate has been discussed. The review also provides an economic overview and future outlook on biodiesel production from microalgae.

Keywords Global carbon cycle · Bio-sequestration · Microalgae · Biofuel · Fossil fuel

\section{Introduction}

Global climate change and increase in the trend of greenhouse gas emissions, as well as the depletion of conventional fuel reserves are a growing concern over the years. The combustion of coal, oil and natural gas emits more than 6 billion tonnes of $\mathrm{CO}_{2}$ annually in the atmosphere as depicted in Fig. 1 (60 Years BP Statistical Review of World Energy 1965-2011).

The United Nations promoted the Kyoto Protocol (1997) with the objective of reducing greenhouse gases such as $\mathrm{CO}_{2}, \mathrm{CH}_{4}, \mathrm{SO}_{2}, \mathrm{NO}_{2}$ by $5.2 \%$ on the basis of the emission in 1990, and more than 170 countries have ratified the protocol (Gutierrez et al. 2008). According to the Intergovernmental Panel on Climate Change, the average concentration of $\mathrm{CO}_{2}$ increased from $315 \mathrm{ppm}$ in 1960 to $380 \mathrm{ppm}$ in the year 2007 and there has been a 35\% increase in $\mathrm{CO}_{2}$ emission worldwide since 1990 (Solomon et al. 2007). This progressive rise of $\mathrm{CO}_{2}$ in today's atmosphere demands dedicated research on the development of appropriate sequestration techniques to reduce the impact of $\mathrm{CO}_{2}$ on global warming. Till date, various $\mathrm{CO}_{2}$ capturing techniques have been represented in Fig. 2. 


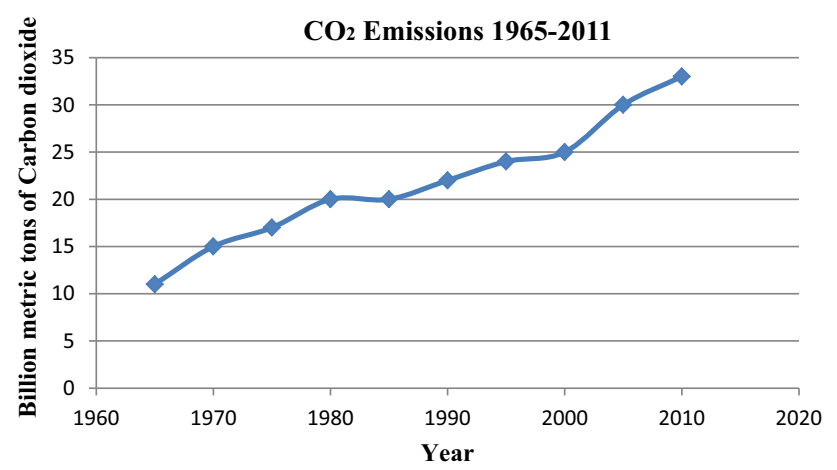

Fig. 1 Graph showing the increasing level of $\mathrm{CO}_{2}$ since 1965 globally. The graph depicts that the growth rate of $\mathrm{CO}_{2}$ in emissions over the past decade is faster than that of previous decadesindicating that $\mathrm{CO}_{2}$ emissions have accelerated in recent years. Since 2002, 1 billion incremental tonnes have been added three times: In 2003, 2004, and 2010 (Solomon et al. 2007)

In this regard, mitigation of $\mathrm{CO}_{2}$ by biological means has been gaining the momentum because it leads to the generation of energy from biomass grown by $\mathrm{CO}_{2}$ fixation through photosynthesis (Kondili and Kaldellis 2007). Photosynthetic $\mathrm{CO}_{2}$ fixation is thought to be a feasible technology as it is energy efficient, sustainable and environmentally benign.

$\mathrm{CO}_{2}$ can be trapped biologically by green plants through photosynthesis. However, the $\mathrm{CO}_{2}$ capture by agricultural plants has been estimated to be only 3-6\% of fossil fuel emissions (Skjanes et al. 2007), as a consequence of slow growth rates of conventional terrestrial plants. On the other hand, microalgae may offer the opportunity due to its abundance and faster growth rate. Microalgae are a group of fast-growing unicellular microorganisms, which has the ability to fix $\mathrm{CO}_{2}$ while capturing solar energy with efficiency 10-50 times greater than that of terrestrial plants ( $\mathrm{Li}$ et al. 2008a, b). The uptake of $\mathrm{CO}_{2}$ from the atmosphere by the microalgal cells is facilitated by the extracellular zinc metalloenzyme carbonic anhydrase (CA). CA catalyzes the conversion of $\mathrm{CO}_{2}$ to bicarbonates, which is taken up by the microalgal cells through specific transporters (Mondal et al. 2016a). Depending upon the species of microalgae the $\mathrm{CO}_{2}$ captured is stored as lipids, carbohydrates or proteins. The $\mathrm{CO}_{2}$ incorporated as lipids in microalgae can be extracted and used as a biofuel. The reaction catalyzed by the carbonic anhydrase enzyme is given by Eq. (1) (Ramanan et al. 2009):

$\mathrm{CO}_{2}+\mathrm{H}_{2} \mathrm{O} \stackrel{\mathrm{CA}}{\longrightarrow} \mathrm{HCO}_{3}^{-}+\mathrm{H}^{+}$

Several microalgal species have been studied for $\mathrm{CO}_{2}$ reduction such as Scenedesmus obliquus, Chlorella kessleri (Morais and Costa 2007b), Dunaliella tertiolecta, Botryococcus braunii, Spirulina platensis (Sydney et al. 2010), Chlorocuccum littorale (Ota et al. 2009), Nannochloropsis oculata (Chiu et al. 2009). These studies have mainly focussed on the effect of various concentrations of $\mathrm{CO}_{2}$ on biomass production. The $\mathrm{CO}_{2}$ sequestration process is also a function of light as well as temperature, $\mathrm{pH}$ and flow rate (Yue and Chen 2005).

The exhaustive use of fossil fuels for the production of energy has led to the global energy crisis and the demand for energy is growing worldwide particularly in many of the rapidly developing countries such as China and India. Considerable amount of food crops which include sugarcane, maize, wheat, soybean, palm oil and sunflower oil and their products are being used for the production of first generation biofuels. Unfortunately biofuel derived from food crops, waste cooking oil, edible oil and other vegetable oils are not enough to meet the increasing demand for transport fuels (Ghosh et al. 2016). Moreover, biofuels from food crops also contribute to land clearing if they are produced on cropland or on newly cleared lands (Chisti
Fig. 2 Schematic representation of the various techniques used for $\mathrm{CO}_{2}$ capture (Source: Rao and Rubin 2002)

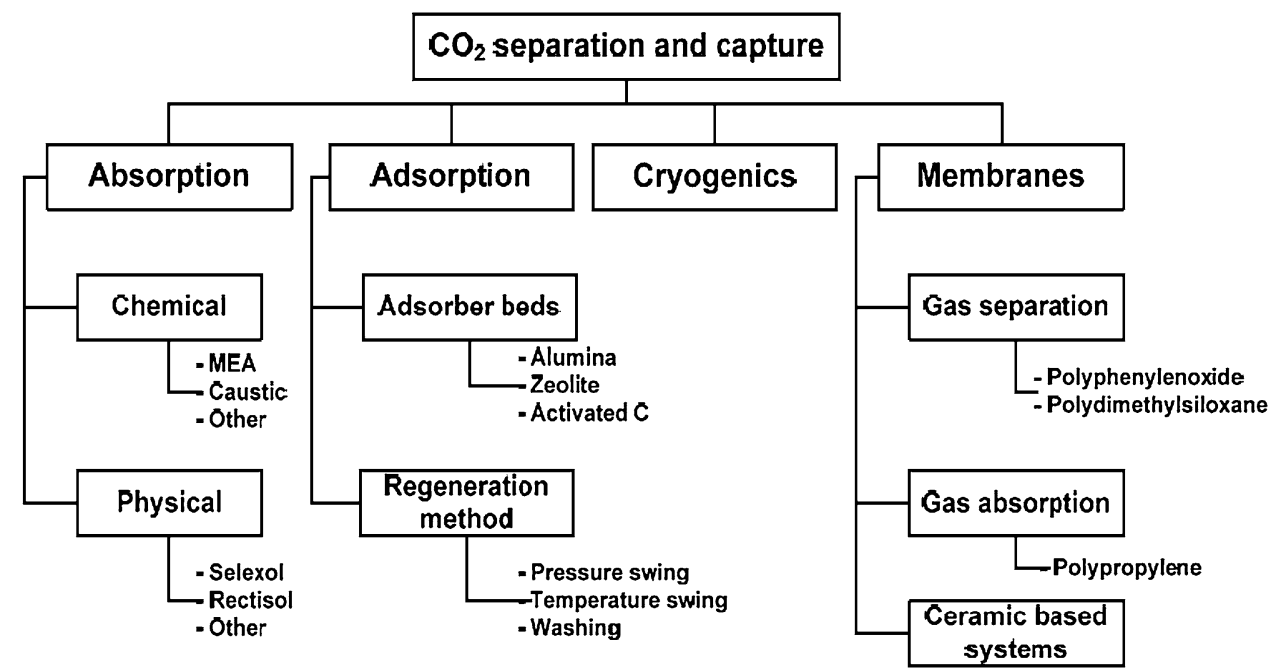


2007; Nepstad et al. 2008). Hence, biofuel produced from the captured $\mathrm{CO}_{2}$ via microalgae could be one of the potential options to reduce the utilization of food-based lignocellulosic biomass.

Microalgal strains like, Synechococcus sp. PCC7942 (Silva et al. 2014), Schizochytrium mangrovi PQ6 (Hong et al. 2013), Chlorococcum parinum (Feng et al. 2014), Chlorella vulgaris (Cheirsilp et al. 2011) have been reported as potential biodiesel feedstock. Many factors influence the lipid accumulation and cell growth of microalgae, such as $\mathrm{CO}_{2}$ concentration, light intensity, temperature and nutrition. Nitrogen and phosphorus are the most crucial elements in the nutrition. It has been reported that nitrogen deficiency leads to higher amount of lipid production in microalgal cells.

The most understudied methods for $\mathrm{CO}_{2}$ capture is the use of the biological route through microalgae in which $\mathrm{CO}_{2}$ is directly converted to biomass from point source emissions of $\mathrm{CO}_{2}$ in specially engineered systems such as photobioreactors (PBRs). Carbon fixation by phototrophic algae has the potential to diminish the emitted $\mathrm{CO}_{2}$ into the atmosphere and thus curtail global warming (Salih 2011). Microalgal bio-fixation of $\mathrm{CO}_{2}$ in photobioreactors is a promising approach for higher biomass and biofuel production. The utilization of photobioreactors for capturing $\mathrm{CO}_{2}$ by microalgae offers principal advantages of higher microalgal productivity due to controlled environmental conditions with optimized space or volume utilization hence, more efficient use of costly land. Thus, microalgae can serve a dual purpose of mitigating global warming through $\mathrm{CO}_{2}$ fixation and generating renewable fuel to satisfy the ever-increasing energy demand.

Biofuel from microalgae appears to be a suitable worldwide solution towards the replacement of conventional fuels such as petrol and diesel. The estimated annual consumption of petroleum in India is about 120 million tonnes per year and only microalgae have the capacity to satisfy this huge demand for petroleum (Darzins et al. 2010). It has been estimated that almost $21 \%$ of the available agricultural land is required for biodiesel production from crops such as soybean or palm to yield oil enough for replacing the petro-diesel, which is not feasible for the developing countries like India. However, if microalgae can be used less than $2-3 \%$ of the total cropping land would be required owing to its high yield of oil per acre of cultivation (Bajhaiya et al. 2010).

This review work attempts to address the potential application of microalgae for the biological $\mathrm{CO}_{2}$ capture and production of biodiesel both in open ponds and photobioreactors. The essential factors which govern biofuel production such as temperature, light intensity, $\mathrm{pH}$, carbon uptake, oxygen generated, mixing rates and nutrient uptake have been discussed. It also gives a clear view of the national and international specifications for making biofuel a reality.

\section{Current scenario of biofuel production from microalgae}

Currently, energy generated from fossils fuels is about $90 \%$ and only $10 \%$ of energy is produced from renewable energy sources (Demirbas 2010). Based on the ever-increasing energy demand it is predicted that the conventional oil reserves will vanish after 2050 (Chen et al. 2011). So, there is an urgent need to develop alternate energy sources towards the mitigation of the energy crisis.

Potential research is being carried out to wipeout dependency on non-renewable energy sources and utilizes renewable biofuels or bio sourced fuels. Biofuel includes biomethanol, bioethanol, biobutanol, biomethane, biohydrogen, biodiesel, etc. (Owolabi et al. 2012). Biodiesel is an immediate option as a renewable fuel source as it contains no sulphur or aromatics and the burning of biodiesel results in substantial reduction of emission of unburned hydrocarbons, carbon monoxide and particulate matter (Ananadhi and Stanley 2012). Attempts have been made to produce biofuel from agricultural crops but the 'food or fuel' controversy compels us to find an alternative source. The alternative source is microalgae since it has a fast growth rate and eliminates the food or fuel controversy.

Green microalgae produce a higher quantity of biofuel in comparison to blue-green algae. Chlorella sp., Chlorococcum sp. and Neochlorosis oleabundans are found to be potential biodiesel feed stocks. However, Haematococcus pluvialis, a red microalga also seems to be a good option for biofuel production (Lei et al. 2012). The production of various types of biofuel greatly depends on feedstock availability and the technological options that can be implemented. The production of biofuel from microalgae is confined to laboratories and small industries at this time.

According to many researchers use of algal biofuels could reduce the Green House Gas emissions from $101,000 \mathrm{~g}$ of $\mathrm{CO}_{2}$ equivalent per million British thermal units (BTU) to 55,440 g (Rittmann 2008). According to United States Environmental Protection Agency Act biodiesel produced from microalgae has the potential to meet the Renewable Fuel Standard (RFS 2007) requirement of Environment Protection Agency (EPA). According to RFS, under the Energy Independence and Security Act of 2007, 15.2 billion gallons of domestic alternative fuels could be produced per year with $50 \%$ less emission of life-cycle GHG than petroleum-based transportation fuels (Santana et al. 2012; Renewable Fuel Standard Program (RFS2) regulatory impact analysis. U.S. Environmental Protection Agency 2010; National algal biofuels technology roadmap: a technology roadmap resulting from the national algal 
biofuels workshop (DOE/EE-0332) U.S. Department of Energy 2010). Therefore, microalgae can serve as a feedstock for large-scale biodiesel production ( $\mathrm{Li}$ et al. 2008a, b).

\section{Algal biology}

Microalgae are microscopic and found in fresh water and marine ecosystems. They are unicellular species which exist individually or in groups. Microalgae are capable of performing photosynthesis using the green house gas $\mathrm{CO}_{2}$ and growing photoautotrophically. They are known to produce almost half of the atmospheric oxygen. The microalgal biodiversity is massive and they represent an almost untapped resource. Most of the microalgal species produce unique products like carotenoids, antioxidants, peptides, fatty acids, toxins and sterols. All the carbons fixed by a microalgal species are stored in the cell as proteins, starch and lipids. Hence, microalgae are the excellent candidates for the generation of biofuel.

Algae reproduction generally takes place by three ways: Vegetative, Sexually, or Asexually. Vegetative reproduction occurs merely by binary fission. Asexual reproduction is achieved by the formation of various types of spores like aplanospores or autospores. In sexual reproduction, the exchange of genetic materials occurs, forming new combinations. This process is governed by three basic methods: Isogamy, Anisogamy and Oogamy which leads to the formation of a zygote. Sexual reproduction does not occur in certain classes like Cyanophyceae. The exchange of genetic material can occur by the formation of conjugation tubes. The two different types of conjugation tube formation are scalariform and lateral conjugation.

A considerable amount of investigation is being carried out around the world and researchers have found suitable microalgal strains that can fix $\mathrm{CO}_{2}$ directly from flue gases and produce biofuel from them. Certain microalgal species including Galdieria partita, Chlorella kessleri, Chlorella sp. T-1, Chlorella KR-1, Chlorella emersonii, Chlorella HA-1, Chlorella ZY-1, Chlorococcum littorale, Synechococcus PCC7942, and Nannochloropsis oculata (Ono and Cuello 2007; Kurano et al. 1995; Maeda et al. 1995; Sung et al. 1998; Yanagi et al. 1995; Morais and Costa 2007a, b; Iwasaki et al. 1998; Kajiwara et al. 1997; Hsueh et al. 2009) can be used to capture carbon dioxide from power plants. An assortment of studies has been performed to study the effect of various $\mathrm{CO}_{2}$ concentrations on the biomass and biofuel production rate among different microalgal species. Bio-ethanol has also been produced by Spirogyra sp. along with fermentation by Zymomonas mobilis and Saccharomyces cerevisiae (Sulfahri et al. 2011). Microalgal species like, Chlorella sorokiniana BTA 9031 isolated from rare sampling sites like coalmines have been utilized for capturing $\mathrm{CO}_{2}$ and further for biodiesel production from the captured $\mathrm{CO}_{2}$ (Mondal et al. 2016a, b).

\section{Photosynthesis and photo oxidation of water}

Photosynthesis is a process carried out by some bacterial species, algae and higher plants. It refers to the method by which these organisms convert the energy of light into chemical energy by harvesting light to drive $\mathrm{CO}_{2}$ fixation. In this way, carbon is recycled from the atmosphere into biomass. A supplementary feature of photosynthesis as carried out by algae is the water-splitting reaction, resulting in the production of oxygen. The photosynthetic reaction takes place in specialized organelles known as chloroplasts. Photosynthesis is carried out in two separate series of steps namely, the biophysical and biochemical reactions. The biophysical reactions take place in the thylakoid discs present in the chloroplasts. It refers to the absorption of photons of light by chlorophyll and accessory pigments such as carotenes and xanthophylls. The water is oxidized and oxygen is released (Fig. 3). In this reaction, Adenosine triphosphate (ATP) and reduced nicotinamide adenine dinucleotide phosphate (NADPH) are formed from the electrons freed from water molecules. The energy produced in the form of ATP and NADPH is used to fix $\mathrm{CO}_{2}$ in the dark reactions. The biochemical reaction occurs in the stroma and the products formed are mainly sugar molecules with some other organic molecules required for cell function and metabolism.

\section{Bio-sequestration of $\mathrm{CO}_{2}$}

The $\mathrm{CO}_{2}$ from the atmosphere gets sequestered during the process of photosynthesis which is performed by microalgae to produce food. There are two methods by which green plants fix $\mathrm{CO}_{2}$ from the atmosphere viz., $\mathrm{C} 3$ and $\mathrm{C} 4$ pathways. The $\mathrm{C} 3$ plants comprise about 250,000 species and $\mathrm{C} 4$ plants have 7500 described species. Most algae use the $\mathrm{C} 3$ pathway (Calvin Cycle) for $\mathrm{CO}_{2}$ fixation. In this pathway, $\mathrm{CO}_{2}$ is combined with a 5-carbon compound to yield two 3 -carbon compounds. The enzyme that catalyzes this reaction is Ribulose-1,5-bisphosphate carboxylase/ oxygenase (RuBisCo). Most algae are photoautotrophs, which mean that they can derive the whole energy required from photosynthesis and all of their carbon requirements from the fixation of $\mathrm{CO}_{2}$.

On the other hand diatoms along with terrestrial crop plants (including maize, sugarcane and millet), are known as $\mathrm{C} 4$ plants because they use a different pathway for $\mathrm{CO}_{2}$ fixation. Rather than using RuBisCo to form two threecarbon compounds, $\mathrm{C} 4$ plants combine $\mathrm{CO}_{2}$ with a three- 
Fig. 3 Schematic mechanisms of photosynthesis and photolysis of photoautotrophic microorganisms. ATP adenosin triphosphate, $\mathrm{CO}_{2}$ carbon dioxide, $\mathrm{CH}_{2} \mathrm{O}$ formaldehyde, $\mathrm{O}_{2}$ oxygen, $\mathrm{H}_{2}$ hydrogen, $\mathrm{H}_{2} \mathrm{O}$ water, $\mathrm{NADPH}$ nicotinamide adenine dinucleotide phosphate, Hase hydrogenase, PSI photosystem I, $P S I I$ photosystem II, $F d$ ferrodoxin, $P C$ platocyanin, $P Q$ plastoquinone

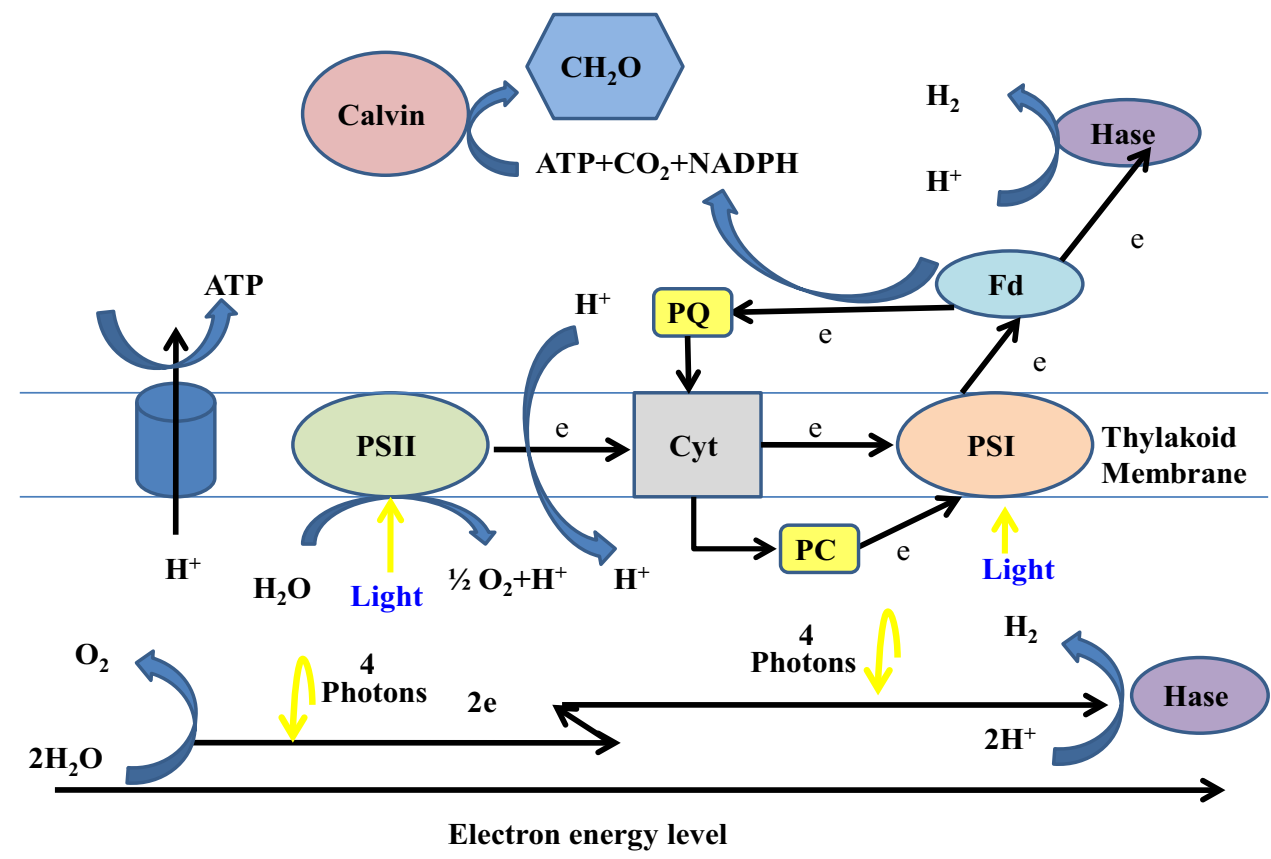

1998). $\mathrm{CA}$ is required in $\mathrm{C} 4$ photosynthesis to convert $\mathrm{CO}_{2}$ to $\mathrm{HCO}_{3}$ in the cytosol, and thus supply PEP carboxylase with substrate. The existence of CA has been proven by the evidences collected from the experiment carried out with CA inhibitors. While CA activities have been examined in a number of micro and macro-algae, most of the current understanding of the role of CA in algae has arisen from studies of the model green alga Chlamydomonas reinhardtii (Badger 2003).

The possible roles of algal cell $\mathrm{CA}$ in $\mathrm{CO}_{2}$ concentrating mechanisms are:

- Promoting active and passive carbon uptake from the environment.

- Delivering externally available $\mathrm{CO}_{2}$ to Rubisco.

- Preventing the leakage of $\mathrm{CO}_{2}$ from the sites of high $\mathrm{CO}_{2}$ concentration in the cell.

A considerable amount of research has been performed on the $\mathrm{CO}_{2}$ mitigation capabilities of some selected microalgal species, the results has been summarized in Table 1. In the $\mathrm{CO}_{2}$ capturing experiments the concentration of $\mathrm{CO}_{2}$ is generally regulated by controlling the flow rates of $\mathrm{CO}_{2}$ with a gas mass flow controller that is monitored by an online $\mathrm{CO}_{2}$ analyzer. In the experiments of Yue and Chen (2005) with Chlorella, ZY-1 high growth rates and cell concentrations were observed at 30 and $50 \%$ $\mathrm{CO}_{2}$ concentrations in the incoming air. At $70 \% \mathrm{CO}_{2}$ concentration strain $\mathrm{ZY}-1$ grew and reached $0.766 \mathrm{~g} \mathrm{~L}^{-1}$ after 6 days of cultivation which was seven times higher than the inoculum cell mass of $0.1 \mathrm{~g} \mathrm{~L}^{-1}$. Whereas Kodama et al. (1993) reported that Chlorococcum littorale inorganic carbon content of the medium (Sultemeyer 
Table 1 Biomass production and carbon capturing capabilities of various microalgal species

\begin{tabular}{|c|c|c|c|c|c|}
\hline Microalgal species & Cultivation system & $\begin{array}{l}\text { Biomass } \\
\text { productivity } \\
\left(\mathrm{g} \mathrm{L}^{-1} \text { day }^{-1}\right)\end{array}$ & $\begin{array}{l}\text { Initial } \mathrm{CO}_{2} \\
\text { concentration }(\%)\end{array}$ & $\begin{array}{l}\mathrm{CO}_{2} \text { fixation rate } \\
\left(\mathrm{g} \mathrm{L}^{-1} \mathrm{day}^{-1}\right)\end{array}$ & References \\
\hline Chlorella vulgaris & Vertical tubular bioreactor & 2.03 & 2 & 0.43 & Yeh and Chang (2011) \\
\hline Chlorella kessleri & Batch, conical flask PBR & 0.87 & 18 & 0.163 & Morais and Costa (2007b) \\
\hline \multirow[t]{4}{*}{ Chlorella sp. } & \multirow[t]{4}{*}{ Semi-continuous PBR } & 1.21 & 2 & \multirow[t]{4}{*}{-} & \multirow[t]{4}{*}{ Chiu et al. (2008) } \\
\hline & & 0.062 & 5 & & \\
\hline & & 0.106 & 10 & & \\
\hline & & 0.099 & 15 & & \\
\hline Scenedesmus obliquss & Erlenmeyer flask & 0.142 & 13.8 & 0.253 & Basu et al. (2013) \\
\hline Chlorococcum littorale & Vertical tubular PBR & 0.120 & - & 0.20 & \\
\hline Chlorella sorokiniana. & Airlift PBR & 0.338 & 5 & 0.619 & Kumar and Das (2012) \\
\hline $\begin{array}{l}\text { Botryococcus } \\
\quad \text { braunii SI-30 }\end{array}$ & Batch PBR & 1.1 & - & 1 & $\begin{array}{l}\text { Murakami and } \\
\text { Ikenouchi (1997) }\end{array}$ \\
\hline $\begin{array}{l}\text { Anabaena sp. ATCC } \\
33047\end{array}$ & Continuous bubble column & 0.31 & 0.2 & 1.45 & Lopez et al. (2009) \\
\hline Spirulina platensis & Fermenter & 2.18 & 5 & 0.32 & Sydney et al. (2010) \\
\hline $\begin{array}{l}\text { Haematococcus } \\
\text { pluvialis }\end{array}$ & Outdoor & 0.076 & $16-34$ & 0.143 & Huntley and Redalje (2007) \\
\hline
\end{tabular}

(a highly $\mathrm{CO}_{2}$ tolerate microalgal strain) had no growth at $70 \% \mathrm{CO}_{2}$. The Chlorella, $\mathrm{ZY}-1$ strain also exhibited a broad range of response against $\mathrm{pH}$ values, it grew well between $\mathrm{pH} 4-6$ and best in $\mathrm{pH} 5.0$. $\mathrm{pH}$ of the medium was reported to rise up to 7.0 at 6th day of cultivation as no measure was taken to control the $\mathrm{pH}$. These results indicated that strain ZY-1 has greater tolerance to high $\mathrm{CO}_{2}$ concentrations and this property can be used to sequester stack gases from thermal power plant.

A microalgal strain Scenedesmus obliquus SA1, isolated from a fresh water body in Assam, India was found to be tolerant to $13.80 \% \mathrm{CO}_{2}$ and $40{ }^{\circ} \mathrm{C}$ temperature. The stack gases that are released from the industries are very hot and the percentage of $\mathrm{CO}_{2}$ present in it is around $12-14 \%$ hence, authors used $13.8 \%$ of $\mathrm{CO}_{2}$ in the incoming air for growing Scenedesmus obliquus SA1. So, it is very important for the $\mathrm{CO}_{2}$ sequestrating microalgal species to also be tolerant to high temperatures. Hence, the strain found by Basu et al. (2013) has proved to be a potential strain for $\mathrm{CO}_{2}$ mitigation of the stack gases. Both the studies used pure $\mathrm{CO}_{2}$ to generate flue gas by mixing it either with air or inert $\mathrm{N}_{2}$, but the effect of heavy metals and other particulate matter on the growth of these species was not studied by any researchers.

Most of the work done on $\mathrm{CO}_{2}$ capture by microalgae focussed on lower $\mathrm{CO}_{2}$ concentrations (below 20\%). The effects of the $\mathrm{CO}_{2}$ concentrations from 5 to $50 \%$ on the growth rate and the productivity of intracellular fatty acids of microalgae have been investigated and it has been concluded that the fatty acid composition and content of microalgae varies significantly (Ota et al. 2009).

One of the main advantages of using microalgae for $\mathrm{CO}_{2}$ capture is that there is no need for the further disposal of the trapped $\mathrm{CO}_{2}$. Carbon fixed by microalgae is incorporated into carbohydrates and lipids which can be used for the production of chemicals, foods, or biofuel from the microalgal biomass (Yue and Chen 2005).

Bio-ethanol can also be produced from different biomass feedstock with higher amount of carbohydrates. Brazil and United States are the two main bio-ethanol producing countries in the world with $62 \%$ of the world production from sugar cane. Microalgae have gained a great attention in the field of bio-ethanol production. Microalgae contain polysaccharides like starch, sugar and cellulose which can be used for the production of bioethanol after fermentation. Chlorella sp., Dunaliella sp. and Scenedesmus sp. are some of the microalgal species which have been reported to possess high amount of starch which can be utilized for bioethanol production (Ozcimen and Inan 2015).

\section{Lipid biosynthesis in algal cells}

Triglycerides (TAG) are the most common lipids found in algal cells formed from fatty acids and glycerol. These lipids are used by algal cells as a storage compound and are similar to the lipids found in vegetable oil. In addition to TAGs, algae produce a number of other lipid types 
including phospholipids (polar lipids, which are composed of two fatty acids and a phosphate group on glycerol, it an essential component of the cell membrane), glycolipids (composed of a glycerol molecule combined with two fatty acids and a sugar molecule, e.g. galactosyldiacylglycerides, found in chloroplast membranes) and sulfolipids (sulphate esters of glycolipids which are also found in chloroplast membranes).

The main biological functions of lipid molecules are energy storage and cell signaling. The biosynthesis process consists of three independently regulated steps:

(i) the synthesis of fatty acids in the plastids,

(ii) formation of glycerol-lipids in the endoplasmic reticulum (ER),

(iii) Packaging into the oil bodies.

The synthesis of fatty acid as shown in Fig. 4 is catalyzed through multifunctional enzyme complex acetylCoA carboxylase (ACCase) which produces malonylcoenzymeA from acetyl-coenzymeA and bicarbonate (Maity et al. 2014).

Acetyl CoA Carboxylase (ACC) is one of the most important biomolecules required for biofuel formation. It is a multi-subunit enzyme found mostly in prokaryotes and in the chloroplasts of plants and algae. This enzyme catalyzes the irreversible carboxylation of acetyl-CoA to produce malonyl-CoA through its two catalytic centres, biotin carboxylase (BC) and carboxyl transferase (CT). In eukaryotic species it is present as a huge, multi-domain enzyme in the endoplasmic reticulum. The function of ACC is to provide

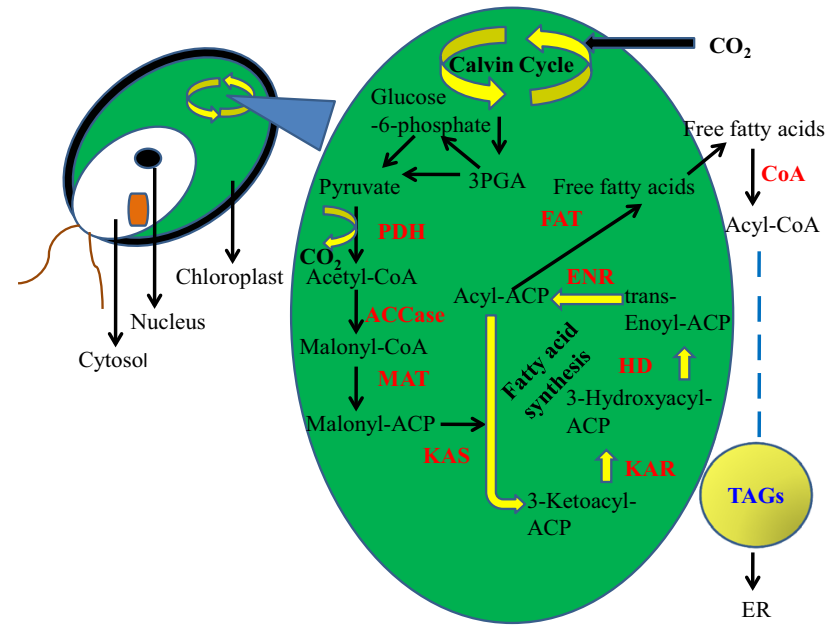

Fig. 4 Schematic representation of microalgal lipid biosynthesis. The enzymes are shown in red. Free fatty acids are synthesized in the chloroplast. The TAGs are assembled at the Endoplasmic Reticulum (ER). ACCase acetyl-CoA carboxylase, $A C P$ acyl carrier protein, $C o A$ coenzyme A, FAT fatty acyl-ACP thioesterase, $P G A$ phosphoglyceraldehyde, $H D$ 3-hydroxyacyl-ACP dehydratase, ENR enoyl-ACP reductase, KAR 3-ketoacyl-ACP reductase, KAS 3-ketoacyl-ACP synthase, MAT malonyl-CoA ACP transacylase, $P D H$ pyruvate dehydrogenase complex, TAG triacylglycerols the substrate for malonyl-CoA that is required for the biosynthesis of fatty acids.

The lipid content in algae can range from 1 to $>50 \%$ and can vary greatly with growth conditions. High levels of TAGs are seen mostly in eukaryotic algae and are not common in cyanobacteria or other prokaryotes in general, though some bacteria have been shown to produce up to $87 \%$ of their dry weight as TAG (Darzins et al. 2010).

Schenk et al. (2008) and Vince et al. (2012) have reported that the lipid content of microalgae was 10-30\% of the dry weight under optimal growth conditions but in some oleaginous species the lipid content increased up to $60-80 \%$ of dry weight when they are exposed to stress conditions such as nutrient deprivation and high light intensity. The fatty acid profiles of some microalgae are summarized in Table 2.

\section{Oil producing microalgal strain selection}

It is noteworthy that successful commercial microalgal growth essentially requires the development of strains and conditions for culture that allow rapid biomass production with high lipid content and minimal growth of contaminating strains. Established strains from culture collections are advantageous as they are readily available as pure culture along with prior knowledge on the strain of choice. Isolation and screening of novel native algae allow the selection of strains adapted to particular climate, water chemistry and other selective conditions such as extremes of $\mathrm{pH}$, temperature, salinity, or ability to grow with flue gas as the $\mathrm{CO}_{2}$ source. Strains that have already shown some promise for lipid productivity may be further improved through the classical genetic techniques of mutagenesis and breeding. The application of genetic engineering techniques and modern methods of systems to biology like, genomics, proteomics, transcriptomics and metabolomics for improvement of the microalgal strain has considerable promise. Thus, selecting the right strain is a very important task for the synthesis of microalgal biofuel.

When comparing different microalgal types, the lipid production rate $\left(\mathrm{mg} \mathrm{L}^{-1}\right.$ day $\left.^{-1}\right)$ in green microalgae is much higher than those of red or blood-red microalgae. The lipid productivity of $C$. protothecoides, $C$. vulgaris CCAP 211/11b, N. oculata NCTU-3 and N. oculata was found to be $>100 \mathrm{mg} \mathrm{L}^{-1}$ day $^{-1}$. Whereas in the contest of lipid content (\% dry weight biomass) and productivity $C$. protothecoides, N. oculata NCTU-3 and N. oleoabundans have exhibited more efficient productivity than others. The lipid content ( $\%$ dry weight biomass) can be summarized in the order of: green algae $>$ Yellow-green algae $>$ red algae $>$ blood-red algae $>$ blue-green algae and lipid productivity (mg L ${ }^{-1}$ day $^{-1}$ ) was observed in the order of: green algae $>$ red algae (Ota et al. 2009). 
Table 2 Summaries of fatty acid profiles of microalgal species (Sung et al. 1999)

\begin{tabular}{llllr}
\hline Microalgal species & Saturated $(\%)$ & Monounsaturated $(\%)$ & Polyunsaturated $(\%)$ & Other $(\%)$ \\
\hline Chlorella vulgaris & 21 & 14 & 51 & 14 \\
Neochloris oleoabundans & 18 & 18 & 44 & 20 \\
Phaeodactylum tricornutum & 24 & 25 & 31 & 20 \\
Nannochloropsis granulate & 21 & 29 & 32 & 3 \\
Isochrysis galbana & 32 & 29 & 36 & 18 \\
Botryocococcus braunii & 0 & 74 & 8 & 3 \\
\hline
\end{tabular}

\section{Bioactive molecules}

Microalgae are prolific producers of natural products. They are not limited to biofuel production only. Through photosynthesis, microalgae process more than $25 \%$ of the annually available inorganic carbon into carbohydrates which serve the other levels of the trophic networks. Microalgae synthesize bioactive molecules such as lipids and pigments that exhibit clinical properties (Mimouni et al. 2012). Some of the bioactive compounds are listed in Table 3. These bioactive compounds are produced when the microalgae are exposed to abiotic stresses, such as nutrient starvation, low temperatures and UV irradiation. A phenotypically altered mutant of cyanobacterium Synechocystis sp. was isolated using chemical mutagenesis and penicillin selection. The strain showed a significant increase in the phycobiliprotein content. The strain could be used for the production of natural colouring agents such as phycobilins (Prasanna et al. 2003). Red microalgae also possess the characteristic pigment phycobiliproteins, which are natural colourants used in pharmaceutical and cosmetic industries. Spirulina (Arthrospira), is grown commercially in open ponds as it is an excellent source of C-phycocyanin (Sekar and Chandramohan 2008). Novel bioactive chemical compounds like carrageenans, fucoidans and ulvans have been isolated from microalgae. Antioxidants and anticancer effects of these compounds are in experimental trials. Carotenoids are yellow to red pigments responsible for colouration in fruits and vegetables. D. salina and $H$. pluvialis has the highest beta-carotene and astaxanthin content, respectively, of any organism (Borowitzka 2013; Cysewski and Lorenz 2004). Carotenoids are used as antioxidants as they are found to reduce the risk of cardiovascular diseases and certain types of cancer like, lung and breast cancer (Gouveia et al. 2010). Microalgal culture systems are used for the production of long chain omega-3 polyunsaturated fatty acids which are important human growth supplements. Since, the biofuel is a low-value product it has been proposed that commercially viable biofuel production can only be possible if the other valuable components of the microalgal biomass are exploited and extracted as co-products (Wijffels and Barba 2010).

\section{Microalgal cultivation}

Microalgae can be grown in open culture systems such as raceway ponds and also in highly controlled closed culture systems like photobioreactors. The growth of microalgal biomass requires light, carbon dioxide, water, organic salts and appropriate temperature. The open systems comprised of ponds containing growth medium, constructed in rows on large areas exposed to sunlight. Rotating paddles are generally used to provide turbulence in the algal suspensions. Maintaining the appropriate supply of $\mathrm{CO}_{2}$ is a very critical factor in open ponds systems and it is maintained by $\mathrm{pH}-$ stat, which warrants both provisions for $\mathrm{CO}_{2}$ and optimum $\mathrm{pH}$ of the culture simultaneously. Closed systems

Table 3 Some of the bioactive compounds obtained from microalgal species and their uses

\begin{tabular}{lll}
\hline Microalgal species & Bioactive compounds & Biological activity \\
\hline Haematococcus & Astaxanthin & Anti-aging agent \\
Dunaliella & Beta-carotene & Anti-cancer agent, coronary disease prevention \\
Arthrospira & Phycocyanin & Anti-oxidant \\
Nannochloropsis & Riboflavin & Micronutrient \\
Tetraselmis & $\alpha$-Tocopherol Anti-oxidant, Anti-inflammatory agent & Nutraceuticals \\
Phacodactylum & Eicosapentanoic acid & Ants \\
\hline
\end{tabular}


are those where growth medium is isolated from the environment and allows exhaustive control of operating conditions. The open systems have many disadvantages when compared to the closed systems. In open systems, biological contamination from the external environment is high and it causes mutation (Znad et al. 2012). Closed systems have less chances of contamination and are easy to monitor as they require less space but they are not cost effective (Campo et al. 2007).

\section{Open pond cultivation}

The choice of cultivation system depends on two factors such as cost and reliability (Odlare et al. 2011). Open pond cultivation can be set up in the form of large tanks or raceway systems. The open pond systems are usually cheaper and simpler because old water tanks can be modified for growing microalgae. Nevertheless, evaporation and culture control remain a challenge in open ponds. Open Culture systems are the main systems used to produce microalgae commercially. It is considered to be the most economical culture systems for large-scale microalgal cultivation. However, its lower biomass productivity is a grave shortcoming bearing in mind the competition of land for traditional crops when commercial developments of microalgae biofuel are promoted. Open ponds have the widest application because they are relatively simple to construct, with low-cost operation and maintenance (Borowitzka 1999; Barbosa et al. 2003).

The illumination intensity of the pond with water-level higher than $200 \mathrm{~mm}$ is below the photo-compensation point for algae nil growth except in the upper thinnest layer (Doucha and Livansky 2006). As a result, growth of microalgae is limited. Thorough mixing may improve the light path increasing the cultivation efficiency. Hence, sunlight is the most predominant factor to influence the growth of microalgae in a pond culture.

Many methods have been developed to increase the cultivation efficiency of the open pond systems. Open ponds have been equipped with new techniques for proper mixing and $\mathrm{CO}_{2}$ mass transfer in the pond. Chen et al. (2013) studied the effect of light/dark cycle in an open pond but with forced light and dark cycles. A biomass productivity of $36.5 \mathrm{~g}^{-2}$ day $^{-1}$ for Scenedesmus dimorphus was achieved in the laboratory. Whereas biomass productivity of outdoor cultivation practice with the forced light/dark cycles were $28.5 \mathrm{~g}^{-2} \mathrm{day}^{-1}$, which is double the value obtained by usual open pond cultivations with 250 or $50 \mathrm{~mm}$ water depth without forced circulation.

The productivity of open pond microalgae cultivation systems is strongly correlated to the location of the pond, the layout of the pond system, microalgae species and weather conditions. Studies have been done with two algal species using the measured weather data for Netherlands and Algeria. The calculation-based results showed that climate conditions such as temperature changes and solar irradiation play very important roles in open race-way ponds. However, there are numerous limitations in open pond culture systems:

(i) poor utilization of light by microalgae cells,

(ii) high evaporation,

(iii) low mass transfer,

(iv) loss or diffusion of $\mathrm{CO}_{2}$ into the atmosphere,

(v) amount of land required

(vi) chemical and biological contamination in the pond.

Hence, it is necessary to select algal species which have a suitable growth rate, light absorption coefficient and have the capability to grow over a broad temperature range (Carlos et al. 2003).

The various seasons have a significant effect on the pond culture systems. An optimized secondary wastewater and $25 \%$ liquor medium was used to study the capability of $C$. luteoviridis and $P$. hussii for full seasonal cultivation in a $150 \mathrm{~L}$ open pond in a temperate climate. Growth was observed for both species throughout the year but growth rate, productivity and remediation characteristics were at the peak in summer and spring (Osundeko and Pittman 2014).

In spite of the many advantages of the open pond systems, closed photobioreactors have become more popular because of the high photosynthetic efficiency and biomass productivity. Photobioreactors enable us to control the environment in which microalgae are cultivated and maintain the purity of the species.

\section{Photobiorectors}

A photobioreactor is principally a bioreactor in which an illuminating source is incorporated so that the organisms growing in it can grow by utilizing the light energy. Bioreactors suitable for $\mathrm{CO}_{2}$ sequestration have the flexibility of using $\mathrm{CO}_{2}$ rich gas as a means of mixing and as a source of $\mathrm{CO}_{2}$ for the growth of algae. Agitation can be done non-mechanically or mechanically by bubbling $\mathrm{CO}_{2}$ rich inlet gas into the photobioreactor. High mass transfer is the requisite criteria for the bioreactors designed especially for $\mathrm{CO}_{2}$ sequestration. $\mathrm{CO}_{2}$ from the gaseous phase transfers into the algal cell through the lipid phase increasing the resistance to mass transfer. Unlike open ponds, photobioreactors can ensure the growth of a single alga species without the interference or competition from other species (Das 2015).

Closed systems can be classified as horizontal tubular photobioreactors; stirred photobioreactors; airlift and bubble column photobioreactors represented in Fig. 5. The 
advantages and disadvantages of the respective PBRs are summarized in Table 4.

Among the different PBRs available for microalgal biomass production, the airlift reactor seems the most suitable reactor for flue gas $\mathrm{CO}_{2}$ sequestration. High gas transfer, uniform mixing, low hydrodynamic stress, and ease of control are the characteristic advantages of this reactor. But, none of these configurations present in the bioreactor can effectively control all the various parameters that are required for utmost microalgal growth, metabolic activity, and bio-fixation of $\mathrm{CO}_{2}$ particularly at large scale production process.

\section{Factors affecting PBR cultivation}

\section{Temperature}

Temperature is one of the major factors responsible for microalgal growth particularly cellular morphology and physiology. The metabolic rates of microalgae are generally accelerated by higher temperatures, whereas inhibition of microalgal growth is caused by lower temperatures (Kumar et al. 2011). The optimal temperature for growth varies among microalgal species ranging from 15 to $26{ }^{\circ} \mathrm{C}$ (Znad et al. 2012) If the microalgae culture is fed with flue gas, then thermophilic organisms are required for $\mathrm{CO}_{2}$ bio-sequestration. Since, Flue gas temperature can be as high as $120^{\circ} \mathrm{C}$.

$p H$

Most microalgal species favour neutral $\mathrm{pH}$, except for the marine species, which prefer $\mathrm{pH}$ values from 8.0 to 8.4. Some species like Spirulina platensis can even tolerate up to $\mathrm{pH}$ 9. Higher biomass productivity can be obtained by increasing the $\mathrm{CO}_{2}$ concentration but when the $\mathrm{CO}_{2}$ concentration is elevated the $\mathrm{pH}$ of the media drops down to 5 which can affect the microalgal physiology adversely (Kumar et al. 2011). In the studies of Basu et al. (2013) the $\mathrm{pH}$ values decreased from $\mathrm{pH} 9.1$ to $\mathrm{pH} 5.3$ for $S$. obliquus
A

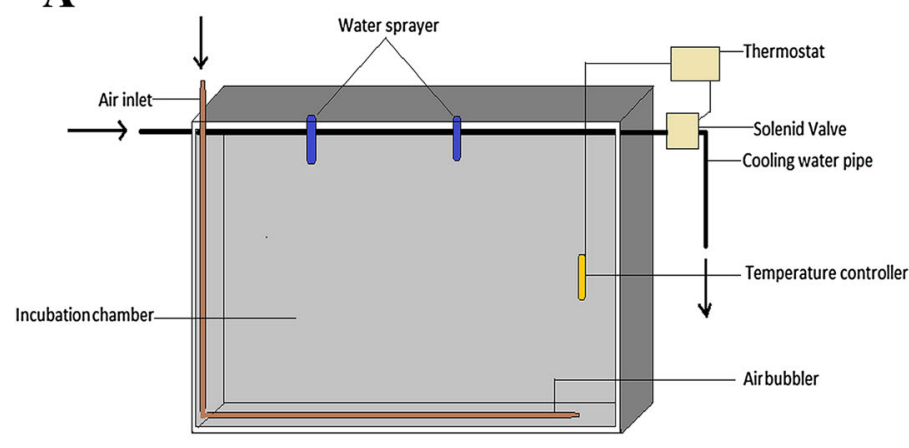

B

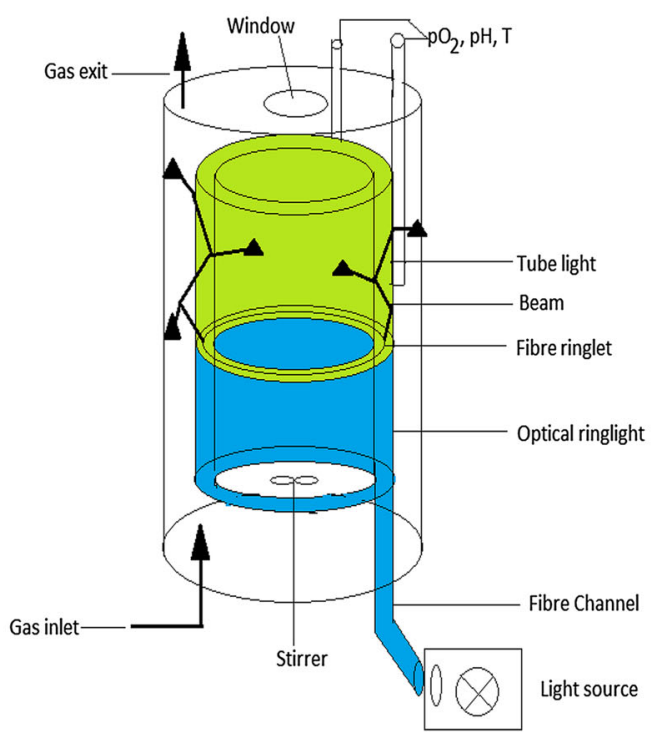

C

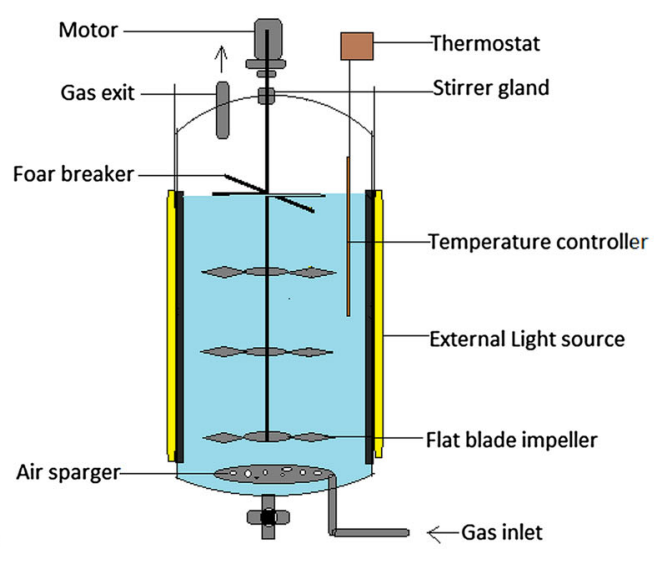

Air Lift Photobioreactor (ALP)

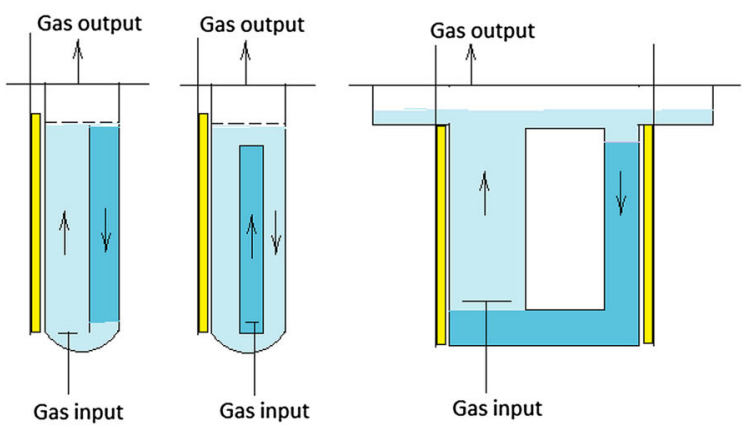

Fig. 5 a-d Diagrammatic representation of the different types of photobioreactors used for microalgal cultivation 
Table 4 Advantages and disadvantages of different PBRs

\begin{tabular}{|c|c|c|}
\hline $\begin{array}{l}\text { Type of } \\
\text { photobioreactor } \\
\text { (PBR) }\end{array}$ & Advantages & Disadvantages \\
\hline $\begin{array}{l}\text { Horizontal tubular } \\
\text { PBR }\end{array}$ & $\begin{array}{l}\text { The shape is itself an advantage for their orientation towards sunlight } \\
\text { which results in high light conversion efficiency }\end{array}$ & $\begin{array}{l}\text { High concentration of dissolved } \mathrm{O}_{2} \text { causes photo } \\
\text { bleaching and reduces photosynthesis efficiency } \\
\text { High energy consumption }\end{array}$ \\
\hline Strirred PBR & $\begin{array}{l}\text { Most conventional reactor, agitation is provided with the help of } \\
\text { impellers } \\
\mathrm{CO}_{2} \text { enriched air bubbled through the bottom }\end{array}$ & $\begin{array}{l}\text { Lack of internal light } \\
\text { Low surface area to volume ratio and mechanical } \\
\text { agitation limits its use }\end{array}$ \\
\hline Airlift PBR & $\begin{array}{l}\text { High mass transfer, good mixing achieved } \\
\text { Good for immobilization of algae }\end{array}$ & $\begin{array}{l}\text { Due to its complexity there is difficulty in scaling } \\
\text { up }\end{array}$ \\
\hline $\begin{array}{l}\text { Bubble column } \\
\text { PBR }\end{array}$ & $\begin{array}{l}\text { Low capital cost, high surface area to volume ratio, lack of moving parts } \\
\text { Satisfactory heat and mass transfer, efficient release of } \mathrm{O}_{2}\end{array}$ & $\begin{array}{l}\text { At gas flow rate less than } \leq 0.01 \mathrm{~m} \mathrm{~s}^{-1} \text { circulation } \\
\text { flow pattern do not exist because of the lack of } \\
\text { back mixing } \\
\text { Lack of internal light }\end{array}$ \\
\hline
\end{tabular}

and from $\mathrm{pH} 8.7$ to $\mathrm{pH} 5.3$ for $C$. pyrenoidosa when the $\mathrm{CO}_{2}$ concentration was increased from 0.03 to $50 \%$. The decrease in $\mathrm{pH}$ also decreases the activity of extracellular CA (Martin and Tortell 2008; Xia and Gao 2005). Moheimani (2005) analyzed the effects low pH, resulting from $\mathrm{CO}_{2}$, which inhibited the algal growth. The maximum productivities of Pleurochrysis carterae in a plate photobioreactor was found to be in the $\mathrm{pH}$ range of 7.7-8.0 and in an outdoor raceway pond was $\mathrm{pH}$ 9.1-9.6. Depending upon the $\mathrm{pH}$, the functional groups present on the surface of the cell may be or not protonated and thus may contribute to autoflocculation of algal cells naturally without any aid from agents (González-Fernández and Ballesteros 2013). So, it is very important to keep the $\mathrm{pH}$ of the media constant using buffered solutions. Sometimes the rise in $\mathrm{pH}$ can be beneficial for the inactivation of pathogens in microalgal culture.

\section{Light}

Light is the energy source for phototrophic microorganisms. Optimum light intensity is necessary for $\mathrm{CO}_{2}$ fixation and biomass generation. Light becomes the limiting factor for the microalgal productivity if it is below the optimum range. While exposing cells for longer duration to high light intensity causes photoinhibition. Znad et al. (2012) reported good microalgal growth rates under a light intensity of $4000 \mu \mathrm{mol} \mathrm{m} \mathrm{m}^{-2} \mathrm{~s}^{-1}$. Periods of low light intensity significantly increases growth, $\mathrm{CO}_{2}$ assimilation and lipid productivity in microalgae.

\section{Carbon uptake}

Microalgae posses a great ability to fix atmospheric $\mathrm{CO}_{2}$. Generally the $\mathrm{CO}_{2}$ sources for microalgae include atmospheric $\mathrm{CO}_{2}, \mathrm{CO}_{2}$ from industrial exhaust gas; and chemically fixed $\mathrm{CO} 2$ in the form of soluble carbonates $\left(\mathrm{NaHCO}_{3}\right.$ and $\mathrm{Na}_{2} \mathrm{CO}_{3}$ ) (Kumar et al. 2010). Microalgal cells preferentially uptake $\mathrm{HCO}^{3-}$ over $\mathrm{CO}_{2}$ despite the fact that former is a poor source of carbon than the latter. Algal cells can tolerate $\mathrm{CO}_{2}$ up to a certain level after which it becomes detrimental for the growth of the cells because the environmental stress induced by the higher $\mathrm{CO}_{2}$ concentration causes biological reduction in the capacity of algal cells for $\mathrm{CO}_{2}$ sequestration (Kumar et al. 2011). When Chlorella sp. BTA 9031 was cultivated in a tubular photobioreactor it produced a biomass concentration of $0.95 \mathrm{~g} \mathrm{~L}^{-1}$ and accumulated $25 \%$ of lipid as a percentage of dry cell weight using $3 \%(\mathrm{v} / \mathrm{v})$ of $\mathrm{CO}_{2}$ supplied from the base of the photobioreactors (Mondal et al. 2016b).

\section{Oxygen generated}

The water splitting activity of photosystem II is responsible for the oxygen evolution during photosynthesis. Trapped oxygen in the liquid culture causes toxic effects like photobleaching and reduces the photosynthetic efficiency. An efficient degassing system is required for the removal of $\mathrm{O}_{2}$ (Kumar et al. 2010). Accumulation of $\mathrm{O}_{2}$ is a serious problem in reactors with poor gas exchange like horizontal tubular reactors. It is not a major concern in reactors which have an open gas transfer area as in stirred tank and vertical reactors.

\section{Mixing rates}

Proper mixing not only promotes uniform mixing of nutrients, but also in better distribution of light over cells. Low mixing rates hampers gaseous mass transfer and cause 
biomass settling. Poor mixing also leads to development of zones with limited light and nutrients and anaerobic conditions are created, which decreases the productivity $(\mathrm{Ku}-$ mar et al. 2011). Conversely, when higher mixing rates are employed cells can be damaged due to shear force (Carlsson et al. 2007). High mixing rates require large energy input. Some of the methods which are used for mixing microalgal bioreactors are mechanical stirring, gas injection or pumping.

\section{Nutrient uptake}

In addition to carbon, nitrogen is the next most important element in the nutrient required for microalgal growth (Becker 1994). Nitrogen is a major constituent of both nucleic acids and proteins. Sometimes certain fast-growing microalgal Species prefer to use ammonium as a primary nitrogen source rather than nitrates (Green and Durnford 1996). When the medium lacks nitrate then intermittent nitrate feeding will enhance microalgal growth (Jin et al. 2006). It has found that when nitrogen is partially available in the growth medium microalgae grow at much lower rates but produce more lipid. Lipids are reserve compounds manufactured by cells under stress conditions even, at the expense of lower productivities (Lardon et al. 2009). Previous studies have shown that under nitrogen (nitrate) limited conditions, nitrogen metabolism in the algal cell decreases, contributing to the increased synthesis of nonnitrogen compounds. Protein synthesis is inhibited due to the lack of $\mathrm{NaNO}_{3}$ (Mata et al. 2010) Biomass concentration is reduced to some extent but lipid content increases. Nigam et al. (2011) reported the same in his study with Chlorella pyrenoidosa. Reduction of concentration of nitrogen from 0.4 to $0 \mathrm{~g} \mathrm{~L}^{-1}$ in the media decreased the biomass production from 0.315 to $0.075 \mathrm{~g} \mathrm{~L}^{-1}$ but lipid content increased by $8 \%$ at exponential phase and by $1 \%$ in the stationary phase. By adding trace elements such as $\mathrm{Mg}$, $\mathrm{Ca}, \mathrm{Zn}, \mathrm{Cu}, \mathrm{Mn}, \mathrm{Mb}$ and vitamins better cultivation can be achieved (Becker 1994).

\section{Harvesting of microalgae}

The harvesting of algae consists of the recovery of biomass from the culture broth. It contributes $20-30 \%$ of the total biomass production cost (Mata et al. 2010). Common harvesting methods include sedimentation, centrifugation and filtration sometimes with an additional flocculation step. Flocculation helps to aggregate the microalgal cells by increasing the effective particle size which eases further sedimentation and filtration processes. Four primary harvesting methods were studied by Weissman and Goebel (1987) for the purpose of biofuel production: microstraining, belt filtering, floatation with float collection and sedimentation. Mechanical simplicity and availability in large unit sizes made microstrainers an attractive harvesting tool. Recently, very fine mesh polyester screens have been available which has revived the use of microstrainers for microalgae harvesting. Alternatively, membrane microfiltration and ultra-filtration are other promising alternatives to conventional filtration processes used for harvesting algal cells.

\section{Processing of microalgal biomass}

After harvesting the algal biomass (5-15\% dry weight), must be quickly processed as it has a tendency to spoil after only in a few hours in a hot climate. Common dehydration is applied since it increases the shelf-life of the final product. Several methods like spray-drying, drum-drying, and sun-drying have been employed for drying microalgal species like Scenedesmus sp, Chlorella sp and Spirulina sp. (Richmond 2004). Since, the algal biomass has a very high water content sun-drying is not a very effective method for algal powder production. Freeze-drying is a very good option for drying of biomass but it is not economically feasible.

\section{Extraction of microalgal lipids}

For biofuel production, lipids and fatty acids from the microalgal biomass need to be extracted. Since the solvent extraction is a quick and efficient extraction method it is normally used to separate the lipids directly from the lyophilized biomass. The lyophilization process removes moisture from the microalgal cells by directly converting water from a frozen state to a gaseous state without going through a liquid phase. The cells remain frozen and in a condition to be directly utilized for extraction. Solvents such as hexane, ethanol (96\%), or a hexane-ethanol (96\%) mixture are generally used (Richmond 2004). The advantage of using an organic solvent for extraction is that it has less reactivity with lipids and can be directly applied to wet feedstock but it is slow and requires a large amount of expensive and toxic solvents. Ultrasonication of microalgal cells reduced extraction times and increases yield. Ultrasound techniques work best at disrupting the tough algal cell-wall of marine microalgae Crypthecodinium cohnii. The extraction yield increased considerably from $4.8 \%$ (in soxhlet) to $25.9 \%$ as the mechanical effect of ultrasonication promotes the release of soluble compounds by disrupting cell walls thereby enhancing mass transfer and facilitating the internalization of solvent into the cells (Mata et al. 2010; Cravotto et al. 2008).

Literature describes successful extraction of algal lipids with supercritical fluids, although on a small-scale, and the 
resulting extract converting into biofuel. Supercritical fluid extraction (SFE) is a promising green and clean technology that has the potential to replace the conventional organic solvent extraction. The extracting ability of a supercritical fluid is a function of its density and it can be adjusted continuously by altering the extraction pressure and temperature. Physical properties of supercritical fluids are intermediary between a liquid and a gas (Santana et al. 2012). The intermediary property allows rapid penetration of the fluid through cell matrices, which results in a higher total lipid yield with a shorter extraction time. The studies performed under various temperature and pressure conditions are tabulated in Table 5 .

The ability of SFE to operate at low temperatures preserves the algal lipid quality during the extraction process and minimizes the need for additional solvent processing. Supercritical $\mathrm{CO}_{2}$ extraction has the potential for the largescale lipid extraction from microalgae. It is rapid, non-toxic and highly selective towards acylglycerols and produces solvent-free lipids but, the high capital cost and the energyneed limits the use of this technology.

Recently, injection of supercritical fluid technology is being carried out for extraction of biodiesel. It is claimed to be an alternative and innovative approach towards the efficient extraction of biodiesel from the feedstock. Similar to the supercritical reaction, the solvent is heated beyond its critical temperature and injected into the vessel containing the feedstock (Ang et al. 2014).

\section{Conversion of microalgal oils into biofuels}

The microalgal lipids which are accumulated as triglycerides can be transformed to fatty acid alkyl esters by transesterification reaction. This reaction is also known as the ester exchange reaction of microalgal lipids. The lipid feedstocks are composed of $90-98 \%$ (by weight) of triglycerides with small amounts of monoglycerides, diglycerides and free fatty acids (1-5\%). Small amounts of phospholipids, phosphatides, tocopherols, carotenes, sulphur compounds and traces of water molecules are also found (Bozbas 2008). TAGs are stored in the specialized oil bodies in the cytosol of the cell. They function as the energy reserve and are more desirable than phospholipids and glycolipids for biodiesel production as they have higher fatty acids content and no phosphate (Jin et al. 2006; Mata et al. 2010).

Transesterification or alcoholysis is a multiple step reaction in which triglycerides are reacted in methanol in the presence of a catalyst. Transesterification chemically means neutralizing the free fatty acids in a triglyceride molecule by removing the glycerin and creating an alcohol ester. In the first step the triglycerides are converted to diglycerides. Then the diglycerides are converted to monoglycerides. Finally the monoglycerides are then converted to esters (biofuel) and glycerol as a by-product. Equation 2 describes the transesterifcation reaction where the radicals $R 1, R 2, R 3$ represent long-chain hydrocarbons, known as fatty acids.

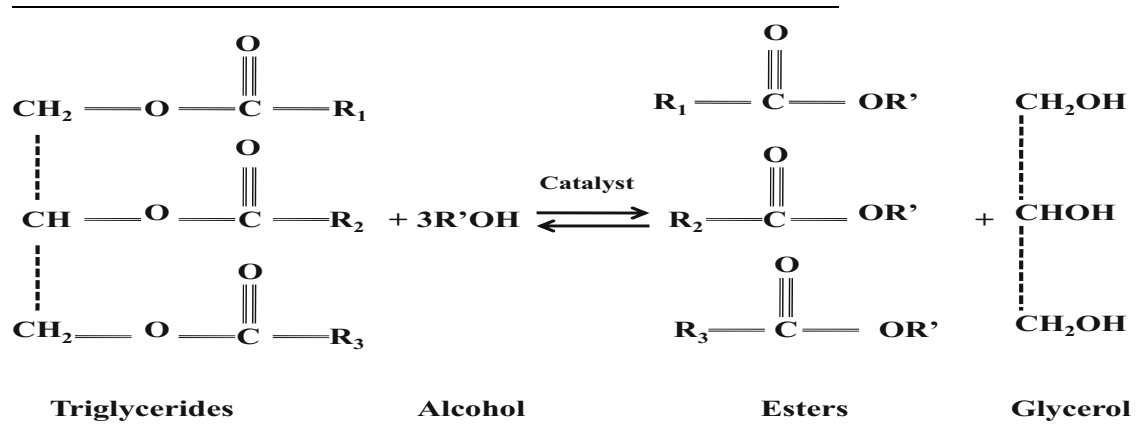

Methanol and Ethanol has been successfully used for supercritical fluid extraction but, these low-carbon alcohols are hygroscopic and corrosive with low energy content. Farobie et al. (2016) suggested the use of 1-propanol as an alternative to methanol and ethanol. More research needs to be performed and the best alcohol could be established by comparing the results obtained from each study.
Transesterification reactions can be acid or base catalyzed in the presence of methanol to produce corresponding fatty acid methyl esters. It is also recently believed that enzyme catalyzed transesterification reaction can increase the yield of biofuel. One such enzyme is the lipase enzyme. The lipase enzyme is obtained from Pseudomonas fluorescence, Candida rugosa, Rhizopus oryzae and Candida antractica (Teo et al. 2014). 
Table 5 Methods and results summary of studies investigating supercritical carbon dioxide extraction of microalgal lipids

\begin{tabular}{|c|c|c|c|c|c|c|}
\hline Study & $\begin{array}{l}\text { Microalgal } \\
\text { species }\end{array}$ & $\begin{array}{l}\text { Extraction pressure } \\
\text { or } P \text { (bar) }\end{array}$ & $\begin{array}{l}\text { Extraction } \\
\text { temperature or } T\left({ }^{\circ} \mathrm{C}\right)\end{array}$ & $\begin{array}{l}\text { Use of } \\
\text { co-solvent }\end{array}$ & $\begin{array}{l}\mathrm{SC}-\mathrm{CO}_{2} \text { flow rate; } \\
\text { extraction time }\end{array}$ & $\begin{array}{l}\% \text { of } \\
\text { Lipid } \\
\text { yield }\end{array}$ \\
\hline Tang et al. (2011) & $\begin{array}{l}\text { Schizochytrium } \\
\text { limacinum }\end{array}$ & 350 & 40 & $\begin{array}{l}\text { Ethanol } \\
\quad(95 \%, \mathrm{v} / \mathrm{v})\end{array}$ & $\begin{array}{l}\text { Not specified; } \\
30 \mathrm{~min}\end{array}$ & 33.9 \\
\hline Mendes et al. (2006) & Spirulina maxima & $100,250,350$ & 50,60 & $\begin{array}{l}\text { Ethanol; } \\
10 \text { mol \% of } \\
\mathrm{CO}_{2}\end{array}$ & $\begin{array}{l}\text { Not specified; } \\
\text { Not specified }\end{array}$ & 3.1 \\
\hline Santana et al. (2012) & Botryococcus braunii & $200-250$ & $50-80$ & None & $\begin{array}{l}\text { Not specified } \\
\text { Not specified }\end{array}$ & 17.6 \\
\hline Cheung (1999) & Hypnea charoides & $241,310,379$ & 40,50 & None & $11 \min ^{-1} ; 120$ & 6.7 \\
\hline Cheng et al. (2011a, b) & Pavlova sp. & 306 & 60 & None & Not specified; 100 & 17.9 \\
\hline Andrich et al. (2006) & Nannochloropsis sp. & $400,550,700$ & 40,55 & None & $\begin{array}{l}0.17 \mathrm{~kg} \mathrm{~min}^{-1} \\
360 \mathrm{~min}\end{array}$ & 25 \\
\hline
\end{tabular}

\section{Effects of various cultivation factors on $\mathrm{CO}_{2}$ sequestration and lipid accumulation by microalgae}

A considerable amount of work has been done on $\mathrm{CO}_{2}$ sequestration and biofuel production from microalgal species. A high $\mathrm{CO}_{2}$ and temperature tolerant microalgae capable of sequestering $\mathrm{CO}_{2}$ from flue gas was isolated and identified as Scenedesmus obliquus (KC733762). At $13.8 \pm 1.5 \% \quad \mathrm{CO}_{2}$ and $25{ }^{\circ} \mathrm{C}$, maximum biomass $\left(4.975 \pm 0.003 \mathrm{~g} \mathrm{~L}^{-1}\right)$ and maximum $\mathrm{CO}_{2}$ fixation rate $\left(252.883 \pm 0.361 \mathrm{mg} \mathrm{L}^{-1}\right.$ day $^{-1}$ ) was obtained which was superior to many other relevant studies. There exists a relationship between the biomass concentration and the $\mathrm{CO}_{2}$ fixation rate of the microalgal species. As the biomass concentration increases more number of cells fix $\mathrm{CO}_{2}$ and hence, the $\mathrm{CO}_{2}$ fixation rate of the culture also increases. The similar nature was observed when the biomass concentration and the $\mathrm{CO}_{2}$ fixation rate of Scenedesmus obliquus, SA1 was plotted and represented graphically in Fig. 6.

At elevated temperatures of $40{ }^{\circ} \mathrm{C}$ and $13.8 \pm 1.5 \%$ $\mathrm{CO}_{2} \quad \mathrm{SA} 1$ gave the maximum biomass of $0.883 \pm 0.001 \mathrm{~g} \mathrm{~L}^{-1}$. Therefore, SA1 proved to be a potential candidate for $\mathrm{CO}_{2}$ sequestration from flue gas, as well as for the production of biofuel (Basu et al. 2013). Higher $\mathrm{CO}_{2}$ concentration and aeration also increased the biomass production and lipid accumulation of Nannochloropsis oculata cultures (Chiu et al. 2009). Similar results were also obtained for Scenedesmus obliquus and Chlorella kessleri cultures which were isolated from a coal fired thermoelectric power plant's treatment pond located in Brazil. It was concluded that these microalgae have the potential to fix $\mathrm{CO}_{2}$ in thermoelectric power plants (Morais and Costa 2007c).

Better growth of microalgal culture in an airlift bioreactor was reported (Kaewpintong 2004). Aeration leads to better mixing of microalgal culture which helps in maintaining homogeneous conditions. Aerated cultures have better contact between cells and nutrients. It also prevents sedimentation. The author has reported that with the increase in the light intensity the cell density, the specific growth rate of the cell increased but only up to a certain limit, above which the growth of microalgal cells were inhibited. The oxygenic photosynthesis and respiration of two distinct microalgal biofilms was studied using a rotating algal biofilm reactor (RABR). Results showed prominent differences in oxygenic photosynthesis and respiration based on different culturing conditions, microalgal composition, light intensity and nitrogen availability. The net areal rate of biofilm photosynthesis, $P_{\mathrm{n}}$ $\left(\% P_{\mathrm{g}}\right)$ for field RABR top biofilm, field RABR bottom biofilm, laboratory RABR nitrate replete and laboratory

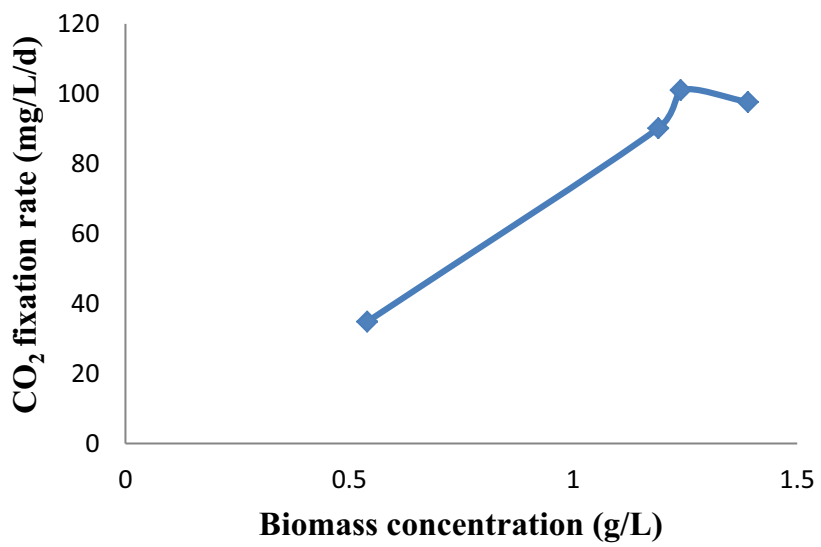

Fig. 6 Graphical representation of the relationship between the biomass concentration and the $\mathrm{CO}_{2}$ fixation rate of Scenedesmus obliquus, SA1 (Basu et al. 2013) 
RABR nitrate deplete were $3.01 \times 10^{-4} \mu \mathrm{mol} \mathrm{O}_{2}$ $\mathrm{cm}^{-2} \mathrm{~s}^{-1} \quad(25.4 \%), \quad 3.55 \times 10^{-4} \mu \mathrm{mol} \quad \mathrm{O}_{2} \quad \mathrm{~cm}^{-2} \mathrm{~s}^{-1}$ (67.9\%), $2.31 \times 10^{-4} \mu \mathrm{mol} \mathrm{O} \mathrm{O}_{2} \mathrm{~cm}^{-2} \mathrm{~s}^{-1}$ (30.8\%) and $2.41 \times 10^{-4} \mu \mathrm{mol} \mathrm{O} \mathrm{cm}^{-2} \mathrm{~s}^{-1}(42.3 \%)$, respectively. The respiration in the dark, $R_{\text {dark }}$ were for field $R A B R$ top biofilm, field RABR bottom biofilm, laboratory RABR nitrate replete and laboratory RABR nitrate deplete were $0.54 \times 10^{-4} \mu \mathrm{mol} \mathrm{O} \mathrm{cm}^{-2} \mathrm{~s}^{-1}, 1.11 \times 10^{-4} \mu \mathrm{mol} \mathrm{O} \mathrm{O}_{2}$ $\mathrm{cm}^{-2} \mathrm{~s}^{-1}, \quad 0.65 \times 10^{-4} \quad \mu \mathrm{mol} \quad \mathrm{O}_{2} \quad \mathrm{~cm}^{-2} \mathrm{~s}^{-1}$ and $0.74 \times 10^{-4} \mu \mathrm{mol} \mathrm{O} \mathrm{Cm}^{-2} \mathrm{~s}^{-1}$, respectively. Areal respiration rates in dark were observed to be two times higher than photosynthesis-coupled respiration rates for the biofilms at the bottom in contrast to the biofilms on top. Hence, bottom biofilms appeared to have a higher capacity for light-independent heterotrophic respiration. According to Myers and Graham (1971) linear relationship existed between dark respiration rate and growth rate in microalgae, whereas Laws and Wong (1978) reported that in some cases it has been observed that decrease in the respiration rates have been observed for some species. The cultures were also evaluated as potential biofuel sources with the results of Gas Chromatography (Bernstein et al. 2014).

To study the effect of nitrogen, as well as salt stress on the proximate chemical compositions, various algal species were grown autotrophically on a mineral medium containing $\mathrm{CO}_{2}$, bicarbonates and nitrates as carbon and nitrogen sources. Under non-stressed conditions, Botryococcus sp. contained the highest concentration of lipids. Green algae, Nitzschia sp. and Isochrysis sp. produced an average of 23, 12 and 7\% per organic weight of lipids (Richmond 2004). The effect of nitrogen stress on algae lipid fraction was studied (Thomas et al. 1984), and it was concluded that cultivation under nitrogen deficient conditions increased the neutral lipid contents significantly for Botryococcus sp. and Isochrysis sp. But halotolerant species like Dunaliella bardawil and Dunaliella salina shifted towards carbohydrate storage under nitrogen stress. Illman et al. found that the drop in nitrogen in the medium enhances the lipid content in five Chlorella strains, among which C. minutissima, C. vulgaris and C. emersonii gained an increase in lipid content of 56, 63, and $40 \%$ biomass by dry weight, respectively (Illman et al. 2000). Macedo and Alegre (2001) also demonstrated that in Spirulina sp lipid content increased about three times at reduced nitrate concentration and temperature.

Lipid accumulation can be induced by high iron concentration in the marine strain C. vulgaris (Liu et al. 2008). From this study it was suggested that there are some metabolic pathways related to lipid accumulation in $C$. vulgaris which are dependent on iron or are most likely customized by growing in a high iron concentration in the initial medium.

\section{Economic overview}

While efforts were being made to commercialise the biofuel conversion process, it was found that huge costs has to be incurred on the production and downstream processing (Das 2015). The cost of building a biodiesel plant depends upon factors like feedstock, location of the plant, plant capacity, plant design and equipment. When biodiesel is produced from Soya or rapeseed oil the cost of biodiesel production increases because the cost of feedstock is the largest expense. Therefore, use of non-edible feedstock like jatropha oil reduces the cost incurred on feedstock to a considerable amount. The economic analysis of Jatropha biodiesel revealed the cost of production of jatropha ethyl ester to be $0.40 €$ per Litre (Nevase et al. 2012) whereas, the cost of production of biodiesel from palm oil is $0.57 €$ per Litre (Chisti 2007). Although the use of non-edible oil for biodiesel production reduces the cost of production yet, there are major drawbacks which prevent the industry to flourish. A jatropha plant takes 2-3 years to grow and produce seeds. Under such circumstances, the various advantages of microalgae over other terrestrial crops make them an interesting perspective for the future. The potential benefits of microalgal feedstocks for biofuel production are summarized below:

- Microalgae grow rapidly and have high per-acre productivity.

- Using microalgae to produce feedstocks for biofuels production will not compromise with the production of food.

- Water used to grow microalgae can include waste water and saline water that cannot be used by conventional agriculture or for domestic use.

- Microalgae have a tremendous technical potential for Green House Gas abatement through the process of biological carbon capture.

- Once the $\mathrm{CO}_{2}$ is trapped with the microalgae there is no need for further removal of the $\mathrm{CO}_{2}$. The $\mathrm{CO}_{2}$ gets converted into lipids and carbohydrates.

- A microalgal bio-refinery could produce an array of coproducts including oils, protein and carbohydrates along with biofuel. Conversion technologies can be integrated for the production of biofuels including biodiesel, green diesel, aviation fuel, methane or green gasoline.

Therefore, microalgae have attracted many industries for the commercialisation of the biofuel production process. Schenk et al. (2008) reported that a sustainable biofuel requires biomass at less than $300 \mathrm{USD}^{-1}$ dry weight. The biomass production costs for three different production systems have been calculated by Norsker et al. 
(2011). He stated that the biomass production cost including the dewatering process for open ponds, horizontal tubular PBRs and flat panel PBRs are 4.95, 4.15 and $5.96 €$ per kilogram, respectively. If the influential factors like irradiation, mixing, media constituents are well optimized then the production cost could be reduced to $0.68 €$ per $\mathrm{kg}$. At this price microalgae could become a promising feedstock for biofuel production (Medipally et al. 2015).

There are numerous funding programs created to promote and assist the use of renewable energy. The sustainable development program (SDTC) has applied \$500 million to assist the construction of next generation renewable fuels. The U.S Department of Energy's Aquatic Species Program focussed only on biodiesel production from microalgae. The National Research council of Canada has provided $\$ 5$ million to a marine research station located in Nova Scotia for growing microalgae. In India also huge amount of money is given by the government towards the research and development of microalgal biofuels. Many companies are working together to produce microalgal biodiesel and cater it to the world. Reliance industries of India has collaborated with the Algenol, USA and commissioned a pilot plant to produce bio-oil in the year 2014 (Algenol and Reliance launch algae fuels demonstration project in India). Origin oils Inc., Sapphire Energy, Solazyme and Genifuels are some of the other companies focused on different aspects of microalgal biofuel production process.

\section{National and International biofuel specifications}

The fuel is a substance which when raised to its ignition temperature burns producing heat, if sufficient oxygen or air is available. The substances classified as fuel must contain the combustible elements like carbon, hydrogen, sulphur, etc. The scientific community throughout the world is putting a lot of effort into creating an alternate energy source which will reduce the use of fossils fuels. The result of this immense research effort is the generation of biofuel. The fuel produced from biological sources like crops, plants or microorganisms is called biofuel. Biofuel has gained worldwide acceptance as a solution to environmental troubles and energy safekeeping. Biodiesel is non-toxic and biodegradable in nature, and it is registered with Environmental Protection Agency (EPA) as a fuel and an additive for fuel. The biofuel produced can be used in reality only if it possesses the characteristics of the existing liquid fuel. So, the biofuel must meet certain international standards like the American Society for Testing and Materials or the EN14214 in Europe.

Development of the standards for biodiesel started in 1990s to encourage the escalating use of biodiesel based on alkyl esters and its blends in car engines. ASTM International adopted the PS121 specification for biodiesel in 1999. In October, 2003 EN 14214 biodiesel standard was finalized based on the former DIN 51606. The US and EU standards have attained international significance and they are considered as the basis for the biodiesel specifications developed in other countries like India. The standard was prepared keeping in view the application, production and feed stock availability. Substantial aid has been taken from ASTM D 6751-02 and EN 14214 while preparing the Indian standard.

The US specification, ASTM D6751, defines biodiesel as mono-alkyl esters of long-chain fatty acids derived from animal fats and vegetable oils. Thus, mono-alkyl esters could be produced with any alcohol, so long as it meets the requirements outlined in the fuel specification (ASTM "Standard Specification for Biodiesel Fuel (B100) Blend Stock for Distillate Fuels 2002). The European biodiesel specification, EN 14214, applies only to mono-alkyl esters made with methanol, fatty acid methyl esters (FAME). The minimum ester content is specified at $96.5 \%$. The addition of components which are not fatty acid methyl esters, other than additives is not allowed (ACEA "Biodiesel Guidelines", European Automobile Manufacturers Association, Brussels, Belgium 2009). The Indian Biodiesel Specification defines biodiesel as a fatty acid alkyl (methyl or ethyl) ester for use as a blend component (up to 20\%) with diesel fuel meeting the requirements of IS 1460 'Automotive diesel fuel Specification' (IS 15607: Bio-diesel (B 100) blend stock for diesel fuel [PCD 3: Petroleum, Lubricants and their Related Products 2005).

If the biofuel generated from microalgae does not meet the specifications then, blending with some other fuel may be required (Fajardo et al. 2007). Al-lwayzy and Yusaf (2013) prepared a blend of petroleum diesel and biodiesel from Chlorella protothecoides. The microalgal biodiesel was obtained after transesterification of the lipid extracted from the microalgae. The performance of the blend was determined by examining the emission of a $25.8 \mathrm{~kW}$ agricultural tractor engine. The physicochemical properties of the blends prepared from microalgae $S$. platensis biodiesel and petro-diesel (B2, B5, B10 and B20) were by Mostafa and El-Gendy (2013). The characteristics of the B5-B20 blends corroborated with the petro-diesel marketed in Egypt. Hence, microalgal biodiesel could be used efficiently by preparing blends with other petro-diesel.

There are also certain guidelines adopted by America and Europe for making biodiesel/fuel blends. The ASTM D6751 standard defines two grades of biodiesel since 2012, grade 2-B (identical to biodiesel defined by earlier versions of the standard) and grade 1-B (with tighter controls on monoglycerides and cold soak filterability). The Biodiesel specifications of America, Europe and India are tabulated 
Table 6 Biodiesel specifications and test methods according to ASTM D6751, EN 14214 and IS 15607

\begin{tabular}{|c|c|c|c|c|c|c|}
\hline \multirow[t]{2}{*}{ Property } & \multicolumn{2}{|l|}{ ASTM D65751-12 } & \multicolumn{2}{|l|}{ EN14214:2012 } & \multicolumn{2}{|l|}{ IS $15607: 2005$} \\
\hline & $1-\mathrm{B}$ & Test & & Test & & Test \\
\hline Density & & & $860-900 \mathrm{~kg} / \mathrm{m}^{3}$ & $\begin{array}{l}\text { EN ISO } 3675 \\
\text { EN ISO } 12185\end{array}$ & $860-900 \mathrm{~kg} / \mathrm{m}^{3}$ & ISO 3675 \\
\hline Flash point & $93^{\circ} \mathrm{C}$ & D93 & $101{ }^{\circ} \mathrm{C}$ & EN ISO 2719 & $120^{\circ} \mathrm{C}$ & \\
\hline Cetane Number & 47 & D613 & 51.0 & EN ISO 5165 & $51 \mathrm{~min}$ & ISO 5156 \\
\hline Cloud point & Report & $\begin{array}{l}\text { D2500 } \\
\text { D4539 }\end{array}$ & Location dependent & EN 23015 & & \\
\hline Ester content & & & $96.5 \% \mathrm{~min}$ & EN 14103 & $96.5 \% \min$ & EN 14103 \\
\hline Water content & & & $500 \mathrm{mg} \mathrm{kg}^{-1}$ & EN ISO 12937 & $500 \mathrm{mg} \mathrm{kg}^{-1}$ & $\begin{array}{l}\text { D2709 } \\
\text { ISO } 3733 \\
\text { ISO } 6296\end{array}$ \\
\hline $\begin{array}{l}\text { Carbon Residue on } 10 \% \\
\text { distillation residue, } \\
\max \end{array}$ & $\begin{array}{l}0.050 \% \\
\mathrm{wt}^{5}\end{array}$ & D4530 & & & $0.050 \% \mathrm{wt}$ & $\begin{array}{l}\text { D4530 } \\
\text { ISO } 10370\end{array}$ \\
\hline Sulphur, max & $\begin{array}{l}\text { Two grades: S15 } 15 \mathrm{ppm} \\
\text { S500 } \\
0.05 \%\end{array}$ & D5453 & $10.0 \mathrm{mg} \mathrm{kg}^{-1}$ & $\begin{array}{l}\text { EN ISO } 20846 \\
\text { EN ISO } 20884 \\
\text { EN ISO } 13032\end{array}$ & $50.0 \mathrm{mg} \mathrm{kg}^{-1}$ & D5453 \\
\hline $\begin{array}{l}\text { Polyunsaturated methyl- } \\
\text { esters, max }\end{array}$ & & & $1.00 \% \mathrm{wt}$ & EN 15779 & & \\
\hline $\begin{array}{l}\text { Monoglycerides, } \\
\text { diglycerides, } \\
\text { triglycerides, max }\end{array}$ & MG $0.4 \%$ wt & D6584 & $\begin{array}{l}\text { MG } 0.70 \% \text { wt } \\
\text { DG } 0.20 \% \text { wt } \\
\text { TG } 0.20 \% \text { wt }\end{array}$ & EN 14105 & & \\
\hline Acid value, $\max$ & $0.50 \mathrm{mg} \mathrm{KOH} / \mathrm{g}$ & D664 & & & $0.50 \mathrm{mg} \mathrm{KOH} / \mathrm{g}$ & EN 14104 \\
\hline Alcohol control & $\begin{array}{l}0.2 \% \text { wt methanol max, or } \\
130^{\circ} \mathrm{C} \text { flash point } \min \end{array}$ & $\begin{array}{l}\text { EN } 14110 \\
\text { D93 }\end{array}$ & $0.20 \%$ wt methanol max & EN 14110 & & \\
\hline Free glycerin, $\max$ & $0.02 \% \mathrm{wt}$ & D6584 & $0.02 \% \mathrm{wt}$ & $\begin{array}{l}\text { EN } 14105 \\
\text { EN } 14106\end{array}$ & $0.02 \% \mathrm{wt}$ & D6584 \\
\hline $\begin{array}{l}\text { Total glycerin, max } \\
\text { Oxidation stability }\end{array}$ & $0.240 \% \mathrm{wt}$ & D6584 & $\begin{array}{l}0.25 \% \mathrm{wt} \\
8 \mathrm{~h} \mathrm{~min}\end{array}$ & $\begin{array}{l}\text { EN } 14105 \\
\text { EN } 14112\end{array}$ & $\begin{array}{l}0.25 \% \mathrm{wt} \\
6\end{array}$ & $\begin{array}{l}\text { D6584 } \\
\text { EN } 14112\end{array}$ \\
\hline
\end{tabular}

min minimum, $\max$ maximum

in Table 6. The guideline for B100 bears resemblance to the EN14214 but there are also certain notable differences including:

- the limitation of blends to B5 maximum

- increasing the oxidation stability of B100 to $10 \mathrm{~h}$,

- fulfilling the condition of oxidative stability that restricts the TAN limit to less than $0.12 \mathrm{mg} \mathrm{KOH} / \mathrm{g}$

- setting up a revised sulphated ash limit of $0.005 \%$ from $0.02 \%$ and redefining the ash limit to $0.001 \%$

- introduction of a ferrous corrosion limit, inclusion of a ferrous corrosion limit, free water and sediment limit

- stringency in the limits of kinematic viscosity, iodine number and flash point were declined

- categorization of pumps disposing blends of B5 or less.

\section{Future perspectives}

Increasing emission of GHG and rapid depletion of conventional fuels has made microalgal biofuel a more compelling renewable and clean alternative fuel source. Microalgae have been shown to be a potential candidate for biological $\mathrm{CO}_{2}$ capture by many researchers. Some strains of Chlorella sp. were found to capture $40 \%$ of $\mathrm{CO}_{2}$, based on these studies $\mathrm{CO}_{2}$ emissions could be pumped from industries and power plants through a sparger system at the bottom of microalgae cultivating open ponds. The captured $\mathrm{CO}_{2}$ is used by the microalgal cells to produce lipids. The algal lipids can be extracted and converted to biodiesel to be used as transportation fuel. Many researchers have 
demonstrated that the microalgal biofuel production through captured $\mathrm{CO}_{2}$ is technically possible but there are currently no biodiesel producing companies in the world based on this route. There is no relevant question whether biofuels from algae are possible, but rather whether they can be made economical and at a scale sufficient to meet the current demand for fuel. However, there are major technical challenges which have to be conquered to achieve this goal. Higher capital and operating cost prevent the commercialization of algal biofuel. The downstream process in microalgal biofuel production consumes a huge amount of energy which increases the cost of production. Hence, recovery of a co-product with high market-value becomes an urgent necessity. Finally, the cost of microalgal biofuel production can be minimized by coupling with microalgal bio-refinery. In the coming decade, genetic and metabolic engineering will play a prominent role in the development of microlagal biofuels for future. Therefore, microalgal biofuel has strengths to overcome controversies in terms of delivering clean and sustainable fuel to the future world while eliminating global warming and food versus fuel concerns.

\section{Conclusion}

Microalgae have attracted a great deal of attention for $\mathrm{CO}_{2}$ fixation and biofuel production because they can capture and convert $\mathrm{CO}_{2}$ into algal biomass by photosynthesis at much higher rates than other crops responsible for generating conventional biofuels. The fixation of $\mathrm{CO}_{2}$ by a biological route could be the most effective carbon-capturing method on earth. Until now most of the work on biological carbon capture by microalgae has been on lower $\mathrm{CO}_{2}$ concentrations $(<20 \%)$. There are few studies available regarding the influence of high $\mathrm{CO}_{2}$ levels (>20\%) on the growth, $\mathrm{CO}_{2}$ biofixation rate and the fatty acid composition of microalgae. There is a need to focus on this area as the concentration of $\mathrm{CO}_{2}$ is rising globally.

Most of the studies reported to date have been conducted on bench scale units under strictly controlled conditions. Certain factors, such as supply of adequate amounts of $\mathrm{CO}_{2}$, nutrients and light should be investigated and optimized for the application of best parametric conditions in production of biodiesel commercially at large scale. The technical feasibility has been proven at small scale and, in fact, small samples of algal biofuel have been produced, but economic feasibility is unknown. To be economically feasible, microalgal biodiesel must be cost-competitive with petroleum-based fuels. The process of biofuel production from microalgae can be made cost-effective by combining the process with utilization of $\mathrm{CO}_{2}$ from point source flue gas emissions, with remediation of wastewater or with the extraction of valuable compounds for application in other industries. The concept of a pond culture is economical but there are certain major environmental conditions required for microalgal growth which can only be fulfilled by employing photobioreactors.

Numerous works have been done on $\mathrm{CO}_{2}$ bio-sequestration and biofuel production by microalgae but still much research is needed to meet the increasing demand for energy. We hope that in the future, biofuel will replace fossil fuel to a large extent and reduce the atmospheric $\mathrm{CO}_{2}$ concentration combating global warming. Hence, it can be concluded that substantial investment in the development of this technology and technical expertise in this area is still required before biofuel can become a reality. The growth of biofuel industries will definitely be economically and environmentally beneficial and at the same time it will create a large number of jobs at different levels of the society.

Acknowledgement Authors wish to express their sincere gratitude and thanks to the Department of Biotechnology, Government of India towards their financial support through sanction number BT/322/NE/ TBP/2012. Authors are also thankful to Mr. Soumya Banerjee, Senior Research Fellow of the Chemical Engineering Department, National Institute of Technology, Durgapur for helping in creating the illustrations included in the review work.

\section{References}

60 Years BP Statistical Review of World Energy 1965-2011 (bp.com/ 60yearsstatisticalreview) (2011)

ACEA "Biodiesel Guidelines", European Automobile Manufacturers Association, Brussels, Belgium (2009)

Algenol and Reliance launch algae fuels demonstration project in India. http://www.greencarcongress.com/2015/01/20150121algenol.html. Accessed 21 Jan 2015

Ananadhi PMR, Stanley SA (2012) Microalgae as an Oil Producer for Biofuel Applications. Res J Recent Sci 1(3):57-62

Al-lwayzy SH, Yusaf T (2013) Chlorella protothecoides microalgae as an alternative fuel for tractor diesel engine. Energies 6:766-783

Andrich G, Zinnai A, Nesti U, Venturi F, Fiorentini R (2006) Supercritical fluid extraction of oil from microalga Spirulina (Arthrospira) platensis. Acta Aliment Hung 35:195-203

Ang GT, Tan KT, Lee KT, Mohamed AR (2014) Biodiesel production via injection of superheated methanol technology at atmospheric pressure. Energy Convers Manag 87:1231-1238

ASTM (2002) Standard specification for biodiesel fuel (B100) blend stock for distillate fuels. Am Soc Test Mater D6751-02

Badger MR (2003) The roles of carbonic anhydrases in photosynthetic $\mathrm{CO}_{2}$ concentrating mechanisms. Photosyn Res 77:83-94

Bajhaiya AK, Mandotra SK, Suseela MR, Kiran T, Ranade S (2010) ALGAL BIODIESEL: the next generation biofuel for India. Asian J Exp Biol Sci 1(4):728-739

Barbosa MJ, Janssen M, Ham N, Tramper J, Wijffels RH (2003) Microalgae cultivation in air-lift reactors: modeling biomass yield and growth rate as a function of mixing frequency. Biotechnol Bioeng 82(2):170-179

Basu S, Roy AS, Mohanty K, Ghoshal AK (2013) Enhanced $\mathrm{CO}_{2}$ sequestration by a novel microalga: Scenedesmus obliquus SA1 
isolated from bio-diversity hotspot region of Assam, India. Bioresour Technol 143:369-377

Becker EW (1994) In "Microalgae: biotechnology and microbiology". Cambridge Univ Press, Cambridge

Bernstein HC, Kesaano M, Moll K, Smith T, Gerlach R, Carlson RP et al (2014) Direct measurement and characterization of active photosynthesis zones inside wastewater remediating and biofuel producing microalgal biofilms. Bioresour Technol 156:206-215

Borowitzka MA (1999) Commercial production of microalgae: ponds, tanks, tubes and fermenters. Prog Ind Microbiol 35:313-321

Borowitzka M (2013) High-value products from microalgae-their development and commercialisation. J Appl Phycol 25:743-756

Bozbas K (2008) Biodiesel as an alternative motor fuel: production and policies in the European Union. Renew Sust Energy Rev 12:542-552

Campo JAD, García-González M, Guerrero MG (2007) Outdoor cultivation of microalgae for carotenoids production: current state and perspectives. Appl Microbiol Biotechnol 74:1163-1174

Carlos J, Cossio BR, Labella D, Niell FX (2003) The feasibility of industrial production of Spirulina (Arthrospira) in Southern Spain. Aquaculture 217(1-4):179-190

Carlsson AS, Beilen JV, Moller R, Clayton D (2007) Micro and micro-algae: utility for industrial applications. University of New York, New York

Cheirsilp B, Suwannarat W, Niyomdecha R (2011) Mixed culture of oleaginous yeast Rhodotorula glutinis and microalga Chlorella vulgaris for lipid production from industrial wastes and its use as biodiesel feedstock. New Biotech 28:362-368

Chen CY, Yeh KL, Aisyah R, Lee DJ, Chang JS (2011) Cultivation, photobioreactor design and harvesting of microalgae for biodiesel production: a critical review. Bioresour Technol 102:71-81

Chen Y, Wang J, Zhang W, Chen L, Gao L, Liu T (2013) Forced light/dark circulation operation of open pond for microalgae cultivation. Biomass Bioenerg 56:464-470

Cheng CD, Pi T, Jang H, Lin S, Lee H (2011a) Comparative study of lipid extraction from microalgae by organic solvent and supercritical $\mathrm{CO}_{2}$. Bioresour Technol 102:10151-10153

Cheng CH, Du TB, Pi HC, Jang SM, Lin YH, Lee HT (2011b) Comparative study of lipid extraction from microalgae by organic solvent and supercritical $\mathrm{CO}_{2}$. Bioresour Technol 102(21):10151-10153

Cheung PCK (1999) Temperature and pressure effects on supercritical carbon dioxide extraction of n-3 fatty acids from red seaweed. Food Chem 65:399-403

Chisti Y (2007) Biodiesel from microalgae. Biotechnol Adv 25:294-306

Chiu SY, Kao CY, Chen CH, Kuan TC, Ong SC, Lin CS (2008) Reduction of $\mathrm{CO}_{2}$ by a high-density culture of Chlorella sp. in a semicontinuous photobioreactor. Bioresour Technol 99:3389-3396

Chiu SY, Kao CY, Tsai MT, Ong SC, Chen CH, Lin CS (2009) Lipid accumulation and $\mathrm{CO}_{2}$ utilization of Nannochloropsis oculata in response to $\mathrm{CO}_{2}$ aeration. Bioresour Technol 100:833-838

Cravotto G, Boffa L, Mantegna S, Perego P, Avogadro M, Cintas P (2008) Improved extraction of vegetable oils under highintensity ultrasound and/or microwaves. Ultrason Sonochem 15:898-902

Cysewski GR, Lorenz RT (2004) Industrial production of microalgal cell-mass and secondary products-species of high potential: Haematococcus. In: Richmond A (ed) Microalgal culture: biotechnology and applied phycology. Blackwell Science, Oxford, pp 281-288

Darzins A, Pienkos P, Edye L (2010) Current status and potential for algal biofuels production. Commercializing 1st and 2nd generation liquid biofuels from biomass. A report to bioenegy task 39. Report T39-T2. http://www.globalbioenergy.org/uploads/media/
1008_IEA_Bioenergy_Task_39_-_Current_status_and potential_for_algal_biofuels_production.pdf

Das D (2015) Perspectives on algal engineering for enhanced biofuel production. Algal biorefinery: an integrated approach. Springer, New York, pp 73-101

Demirbas A (2010) Social, economic, environmental and policy aspects of biofuels. Energy Educ Sci Technol Part B Soc Educ Stud 2:75-109

Doucha J, Livansky K (2006) Productivity, $\mathrm{CO}_{2} / \mathrm{O}_{2}$ exchange and hydraulics in outdoor open high density microalgal (Chlorella sp.) photobioreactors operated in a Middle and Southern European climate. J Appl Phycol 18(6):811-826

Fajardo AR, Cerdan LE, Medina AR, Fernandez FGA, Moreno PAG (2007) Lipid extraction from the microalga Phaeodactylum tricornutum. Eur J Lipid Sci Technol 109:120-126

Farobie O, Leow ZYM, Samanmulya T, Matsumura Y (2016) New insights in biodiesel production using supercritical 1-propanol. Energy Convers Manag 124:212-218

Feng P, Deng Z, Huc Z, Wangb Z, Fan L (2014) Characterization of Chlorococcum pamirum as a potential biodiesel feedstock. Bioresour Technol 162:115-122

Ghosh A, Khanra S, Mondal M, Halder G, Tiwari ON, Saini S, Bhowmick TK, Gayen K (2016) Progress toward isolation of strains and genetically engineered strains of microalgae for production of biofuel and other value added chemicals: a review. Energy Convers Manag 113:104-118

González-Fernández C, Ballesteros M (2013) Microalgae autoflocculation: an alternative to high-energy consuming harvesting methods. J Appl Phycol 25:991-999

Gouveia L, Marques AE, Sausa JM, Bandarra NM (2010) Microalgae-source of natural bioactive molecules as functional ingredients. Food Sci Technol Bull: Funct Foods 7(2):21-37

Green BR, Durnford DG (1996) The chlorophyll-carotenoid proteins of oxygenic photosynthesis. Ann Rev Plant Physiol Plant Mol Biol 47:685-714

Gutierrez R, Gutierrez-Sanchez R, Nafidi A (2008) Trend analysis using non-homogeneous stochastic diffusion processes. Emission of $\mathrm{CO}_{2}$; Kyoto protocol in Spain. Stoch Environ Res Risk Assess 22:57-66

Hsueh HT, Li WJ, Chen HH, Chu H (2009) Carbon bio-fixation by photosynthesis of Thermosynechococcus sp.CL-1 and Nannochloropsis oculata. J Photochem Photobiol Biol 95:33-39

Huntley ME, Redalje DG (2007) $\mathrm{CO}_{2}$ mitigation and renewable oil from photosynthetic microbes: a new appraisal. Mitig Adapt Strat Glob Change 12:573-608

Illman AM, Scragg AH, Shales SW (2000) Increase in Chlorella strains calorific values when grown in low nitrogen medium. Enzyme Microb Tech 27:631-635

IS 15607 (2005) Bio-diesel (B 100) blend stock for diesel fuel (PCD 3: Petroleum, Lubricants and their Related Products). https:// archive.org/stream/gov.in.is.15607.2005/is.15607.2005_djvu. Accessed 25 June 2015

Iwasaki I, Hu Q, Kurano N, Miyachi S (1998) Effect of extremely high- $\mathrm{CO}_{2}$ stress on energy distribution between photosystem I and photosystem II in a 'high- $\mathrm{CO}_{2}$ ' tolerant green alga, Chlorococcum littorale and the intolerant green alga Stichococcus bacillaris. J Photochem Photobiol Biol 44:184-190

Jin HF, Lim BR, Lee K (2006) Influence of nitrate feeding on carbon dioxide fixation by microalgae. J Environ Sci Health A Tox Hazard Subst Environ Eng 41:2813-2824

Kaewpintong K (2004) Cultivation of Haematococcus pluvialis in Airlift Bioreactor. Master thesis in Chemical Engineering, Department of Chemical Engineering, Chulalongkorn University

Kajiwara S, Yamada H, Ohkuni N, Ohtaguchi K (1997) Design of the bioreactor for carbon dioxide fixation by Synechococcus PCC7942. Energy Convers Manag 38:529-532 
Kodama M, Ikemoto H, Miyachi S (1993) A new species of highly $\mathrm{CO}_{2}$-tolerant fast growing marine microalga suitable for high density culture. J Mar Biotech 1:21-25

Kondili EM, Kaldellis JK (2007) Biofuel implementation in East Europe: current status and future prospects. Renew Sust Energy Rev 11(9):2137-2151

Kumar K, Das D (2012) Growth characteristics of Chlorella sorokiniana in airlift and bubble column photobioreactors. Bioresour Technol 116:307-313

Kumar A, Ergas S, Yuan X, Sahu A, Zhang Q, Dewulf J et al (2010) Enhanced $\mathrm{CO}_{2}$ fixation and biofuel production via microalgae: recent developments and future directions. Trends Biotechnol 28:371-380

Kumar K, Dasgupta CN, Nayak B, Lindblad P, Das D (2011) Development of suitable photobioreactors for $\mathrm{CO}_{2}$ sequestration addressing global warming using green algae and cyanobacteria. Bioresour Technol 102:4945-4953

Kurano N, Ikemoto H, Miyashita H, Hasegawa T, Hata H, Miyachi S (1995) Fixation and utilization of carbon dioxide by microalgal photosynthesis. Energy Convers Manag 36(6-9):689-692

Lardon L, Helias A, Sialve B, Steyer JP, Bernard O (2009) Life-cycle assessment of biodiesel production from microalgae. Environ Sci Technol 43:6475-6481

Laws EA, Wong DCL (1978) Studies of carbon and nitrogen metabolism by three marine- phytoplankton species in nitratelimited continuous culture. J Phycol 14:406-416

Lei A, Chen H, Shen G, Hu Z, Chen L, Wang J (2012) Expression of fatty acid synthesis genes and fatty acid accumulation in Haematococcus pluvialis under different stressors. Biotechnol Biofuels 5:18

Li Q, Du W, Liu D (2008a) Perspectives of microbial oils for biodiesel production. Appl Microbiol Biotechnol 80:749-756

Li Y, Horsman M, Wu N, Lan CQ, Dubois-Calero N (2008b) Biofuels from microalgae. Biotech Prog 24(4):815-820

Liu ZY, Wang GC, Zhou BC (2008) Effect of iron on growth and lipid accumulation in Chlorella vulgaris. Bioresour Technol 99:4717-4722

Lopez CVG, Fernandez FGA, Sevilla JMF, Fernandez JFS, Garcia MCC, Grima EM (2009) Utilization of the cyanobacteria Anabaena sp. ATCC 33047 in $\mathrm{CO}_{2}$ removal processes. Bioresour Technol 100(23):5904-5910

Macedo RVT, Alegre RM (2001) Influence of nitrogen content in the cultivation of Spirulina maxima in two temperature levels - Part II. Food Sci Technol 21:183-186

Maeda K, Owada M, Kimura N, Omata K, Karube I (1995) $\mathrm{CO}_{2}$ fixation from the flue gas on coal-fired thermal power plant by microalgae. Energy Convers Manag 36(6-9):717-720

Maity JP, Bundschuh J, Chen CY, Bhattacharya P (2014) Microalgae for third generation biofuel production, mitigation of greenhouse gas emissions and wastewater treatment: Present and future perspectives: a mini review. Energy 78:104-113

Martin CL, Tortell PD (2008) Bicarbonate transport and extracellular carbonic anhydrase in marine diatoms. Physiol Plant 133:106-116

Mata TM, Martins AA, Caetano NS (2010) Microalgae for biodiesel production and other applications: a review. Renew Sust Energy Rev 14:217-232

Medipally SR, Yusoff FM, Banerjee S, Shariff M (2015) Microalgae as sustainable renewable energy feedstock for biofuel production. BioMed Res Int Article ID 519513, p 13

Mendes RL, Reis AD, Palavra AF (2006) Supercritical CO extraction of $\gamma$-linolenic acid and other lipids from Arthrospira (Spirulina) maxima: comparison with organic solvent extraction. Food Chem 99:57-63

Mimouni V, Ulmann L, Pasquet V, Mathieu M, Bougaran G, Cadoret JP, Morant-Manceau A, Schoefs B (2012) The potential of microalgae for the production of bioactive molecules of pharmaceutical interest. Curr Pharm Biotechnol 13(15):2733-2750

Moheimani NR (2005) The culture of Coccolithophorid Algae for carbon dioxide bioremediation. $\mathrm{PhD}$ thesis, Murdoch University

Mondal M, Ghosh A, Sharma AS, Tiwari ON, Gayen K, Mandal MK, Halder GN (2016a) Mixotrophic cultivation of Chlorella sp. BTA 9031 and Chlamydomonas sp. BTA 9032 isolated from coal field using various carbon sources for biodiesel production. Energy Convers Manag 124:297-304

Mondal M, Khanra S, Tiwari ON, Gayen K, Halder GN (2016a) Role of carbonic anhydrase on the way to biological carbon capture through microalgae - a mini review. doi:10.1002/ep.12394

Morais MG, Costa JAV (2007a) Biofixation of carbon dioxide by Spirulina sp. and Scenedesmus obliquus cultivated in a threestage serial tubular photobioreactor. J Biotechnol 129:439-445

Morais MG, Costa JAV (2007b) Carbon dioxide fixation by Chlorella kessleri, C. vulgaris, Scenedesmus obliquus and Spirulina sp. cultivated in flasks and vertical tubular photobioreactors. Biotechnol Lett 29:1349-1352

Morais MG, Costa JAV (2007c) Isolation and selection of microalgae from coal fired thermoelectric power plant for biofixation of carbon dioxide. Energy Convers Manag 48:2169-2173

Moroney JV, Ynalvez RA (2007) Proposed carbon dioxide concentrating mechanism in Chlamydomonas reinhardtii. Eukaryot Cell 6:1251-1259

Mostafa SSM, El-Gendy NS (2013) Evaluation of fuel properties for microalgae Spirulina platensis bio-diesel and its blends with Egyptian petro-diesel. Arab J Chem doi:10.1016/j.arabjc.2013. 07.034

Murakami M, Ikenouchi M (1997) The biological $\mathrm{CO}_{2}$ fixation and utilization project byrite (2)-screening and breeding of microalgae with high capability in fixing $\mathrm{CO}_{2}$. Energy Convers Manag 38:493-497

Myers J, Graham JR (1971) The photosynthetic unit in Chlorella measured by repetitive short flashes. Plant Physiol 48:282-286

Nepstad DC, Stickler CM, Soares Filho B, Merry F (2008) Interactions among Amazon land use, forest and climate for a near term forest tipping point. Philos Trans R Soc Lond B Biol Sci 363(1498): 1737-1746

Nevase SS, Gadge SR, Dubey AK, Kadu BD (2012) Economics of biodiesel production from Jatropha oil. J Agricult Technol 8(2):657-662

Nigam S, Rai PM, Sharma R (2011) Effect of Nitrogen on Growth and Lipid Content of Chlorella pyrenoidosa. Am J Biochem Biotechnol 7(3):124-129

Norsker NH, Barbosa MJ, Vermu MH, Wijffels RH (2011) Microalgal production - a close look at the economics. Biotechnol Adv 29(1):24-27

Odlare M, Nehrenheim E, Ribe V, Thorin E, Gavare M, Grube M (2011) Cultivation of algae with indigenous species- potentials for regional biofuel production. Appl Energy 88:3280-3285

Ono E, Cuello JL (2007) Carbon dioxide mitigation using thermophilic cyanobacteria. Biosyst Eng 96(1):129-134

Osundeko O, Pittman JK (2014) Implications of sludge liquor addition for wastewater-based open pond cultivation of microalgae for biofuel generation and pollutant remediation. Bioresour Technol 152:355-363

Ota M, Kato Y, Watanabe H, Watanabe M, Sato Y, Smith RL et al (2009) Fatty acid production from a highly $\mathrm{CO}_{2}$ tolerant alga, Chlorocuccum littorale, in the presence of inorganic carbon and nitrate. Bioresour Technol 100:5237-5242

Owolabi RU, Adejumo AL, Aderibigbe AF (2012) Biodiesel: fuel for the future (a brief review) international. J Energy Eng 2(5):223-231

Ozcimen D, Inan B (2015) An overview of Bioethanol production from Algae. Biofuels-Status and Perspective. doi: 10.5772/59305 
Prasanna R, Dhar DW, Dominic TK, Tiwari ON, Singh PK (2003) Isolation and Characterisation of Phycobilin rich mutant of cyanobacterium Synechocystis sp. Ata Biologica Hungarica 54:113-120

Ramanan R, Kannan K, Vinayagamoorthy N, Ramkumar KM, Devi SS, Chakrabarti T (2009) Purification and characterization of a novel plant-type carbonic anhydrase from Bacillus subtilis. Biotechnol Bioprocess Eng 14:32-37

Rao AB, Rubin ES (2002) A technical, economic, and environmental assessment of amine-based $\mathrm{CO}_{2}$ capture technology for power plant greenhouse gas control. Environ Sci Technol $36: 4467-4475$

Richmond A (2004) Handbook of microalgal culture: biotechnology and applied phycology. Blackwell, Oxford

Rittmann BE (2008) Opportunities for renewable bioenergy using microorganisms. Biotechnol Bioeng 100(2):203-212

Salih FM (2011) Microalgae tolerance to high concentrations of carbon dioxide: a review. JEP 2:648-654

Santana A, Jesusa S, Larrayozb MA, Filho RM (2012) Supercritical carbon dioxide extraction of algal lipids for the biodiesel production. Proc Eng 42:1755-1761

Schenk PM, Thomas-Hall SR, Stephens E, Markx UC, Mussgnug JH, Posten C, Kruse HB (2008) Second generation biofuels: highefficiency microalgae for biodiesel production. Bioenergy Res $1: 20-43$

Sekar S, Chandramohan M (2008) Phycobiliproteins as a commodity: trends in applied research, patents and commercialization. J Appl Phycol 20:113-136

Silva CSP, Stenico-Silva ME, Fiore MF, de Castro HF, Da Ros PCM (2014) Optimization of the cultivation conditions for Synechococcus sp. PCC7942 (cyanobacterium) to be used as feedstock for biodiesel production. Algal Res 3:1-7

Skjanes K, Lindblad P, Muller J (2007) $\mathrm{BioCO}_{2}-\mathrm{A}$ multidisciplinary, biological approach using solar energy to capture $\mathrm{CO}_{2}$ while $\mathrm{H}_{2}$ and high value products. Biomol Eng 24:405-413

Solomon S, Qin D, Manning M, Chen Z, Marquis M, Avery KB, IPCC, Climate Change et al (2007) The physical science basis, contribution of working Group I to the fourth Assessment Report of the Intergovernmental Panel on climate change. Cambridge Univ Press, Cambridge

Sulfahri MS, Sunarto E, Irvansyah MY, Utami RS, Sarwoko SM (2011) Ethanol production from Algae Spirogyra with Fermentation by Zymomonas mobilis and Saccharomyces cerevisiae. J Basic Appl Sci Res 1(7):589-593

Sultemeyer D (1998) Carbonic anhydrase in eukaryotic algae: characterization, regulation and possible function during photosynthesis. Can J Bot Rev Can Bot 76:962-972

Sung KD, Lee JS, Shin CS (1998) Isolation of a new highly $\mathrm{CO}_{2}$ tolerant fresh water microalgae Chlorella sp. KR-1. Korean J Chem Eng 15(4):449-450

Sung KD, Lee JS, Shin CS, Park SC, Choi MJ (1999) $\mathrm{CO}_{2}$ fixation by Chlorella sp. KR-1 and its culture characteristics. Bioresour Technol 68:269-273
Sydney EB, Sturm W, de Carvalho JC, Thomaz-Soccol V, Larroche C, Pandey A et al (2010) Potential carbon dioxide fixation by industrially important microalgae. Bioresour Technol 101(15):5892-5896

Tang S, Qin C, Wang H, Li S, Tian S (2011) Study on supercritical extraction of lipids and enrichment of DHA from oil-rich microalgae. J Supercrit Fluids 57:44-49

Teo CL, Jamauddin H, Zain NAM, Idris A (2014) Biodiesel production via lipase catalysed transesterification of microalgae lipids from Tetraselmis sp. Renew Energy 68:1-5

Thomas WH, Tornabene TG, Weissman J (1984) Screening for lipid yielding microalgae: activities for 1983; National Renewable Energy Laboratory (U.S.); Oak Ridge, Tenn. Distributed by the Office of Scientific and Technical Information, U.S. Dept. of Energy

U.S. Department of Energy (2010) National algal biofuels technology roadmap: a technology roadmap resulting from the national algal biofuels workshop (DOE/EE-0332)

U.S. Environmental Protection Agency (2010) Renewable Fuel Standard Program (RFS2) regulatory impact analysis. http:// www.epa.gov/otaq/renewablefuels/420r10006.pdf. Accessed 30 June 2010

Vince O, Wendy A, Peter B, van Johanes S, Csaba L (2012) Changes in lipid, protein and pigment concentrations in nitrogen-stressed Chlorella minutissima cultures. J Appl Phycol 24:907-914

Weissman JC, Goebel RP (1987) Design and analysis of microalgal open pond systems for the purpose of producing fuels. US Department of Energy, Contract no: Contract No. DE-AC0283CH10093, pp 64-67

Wijffels RH, Barba E (2010) An outlook on microalgal biofuels. Science 329:796-799

Xia JR, Gao KS (2005) Impacts of elevated $\mathrm{CO}_{2}$ concentration on biochemical composition, carbonic anhydrase, and nitrate reductase activity of freshwater green algae. J Integr Plant Biol 47:668-675

Yanagi M, Watanabe Y, Saiki H (1995) $\mathrm{CO}_{2}$ fixation by Chlorella sp. HA-1 and its utilization. Energy Convers Manag 36(6-9):713-716

Yang X, Xiang W, Zhang F, Wu H, He H, Fan J (2013) Adaptability of oleaginous microalgae Chlorococcum alkaliphilus MC-1 cultivated with flue gas. Sheng Wu Gong Cheng Xue Bao 29:370-381

Yeh KL, Chang J (2011) Nitrogen starvation strategies and photobioreactor design for enhancing lipid content and lipid production of a newly isolated microalga Chlorella vulgaris ESP-31: implication for biofuel. Biotechnol J 6:1358-1366

Yue L, Chen W (2005) Isolation and determination of cultural characteristics of a new highly $\mathrm{CO}_{2}$ tolerant fresh water microalgae. Energy Convers Manag 46:1868-1876

Znad H, Naderi G, Ang HM, Tade MO (2012) $\mathrm{CO}_{2}$ biomitigation and biofuel production using microalgae: photobioreactors developments and future directions. In: advances in Chemical Engineering, pp 230-244 